\title{
Folkelige og sociale bevagelser. Nyere forskningsretninger og kvalitative forståelser
}

\author{
En indkredsning af et vanskeligt historisk problemkompleks
}

\section{Af Vagn Wåhlin}

Det vil i denne artikel ikke blive forsøgt i leksikalsk forstand at give en kortfattet definition på, hvad de folkelige bevægelser egentlig er for nogle fænomener. I stedet vil jeg afgrænse og særligt indkredse historiskkontekstuelt og tematisk, hvad problemfeltet drejer sig om, ligesom jeg vil fremlægge nogle nyere opfattelser deraf samt endelig skitsere nogle tværvidenskabelige tilgangsveje til forståelse af og forskning i emnet. Til st $\varnothing t t e$ for behandlingen har jeg (nogle få sider fremme) gengivet et større skema over alle hovedgrupperingerne af de folkelige bevægelser samt vist to dynamiske og processuelle modeller for dele af bevægelserne, Fig. I og II. Af vigtige forhold har jeg her af omfangsmæssige grunde ikke kunnet behandle kvindebevægelsen og afholdssagen, men særligt må det ud fra den grundtvigske virkningshistories synsvinkel beklages, at jeg har måttet lade den kirkeligt-kristelige dimension ligge. Af oversigtskemaet kan læserne dog se, at det manglende i hovedsagen oprindeligt er medtænkt. Vedrørende den allernyeste debat om Grundtvigs og den grundtvigske arvs betydning efter postmoderniteten og i dag efter år 2000 henviser jeg til Kim Arne Pedersens udmærkede oversigtsartikel derom, 'Grundtvig på anklagebænken' i Grundtvig-Studier (2002), $184 \mathrm{ff}$. Gennem de folkelige bevægelser og disses foreningsnetværk og institutioner blev der givet samfundsforandrende rum og mæle til væsentlige inspirationer fra N. F. S. Grundtvigs tankeverden og virke. Grundtvigs virkningshistorie kan ikke forstås og beskrives uden en grundig og omfattende inddragelse af de folkelige bevægelser i interessefeltet, selvom de folkelige bevægelsers samfundsmæssige virke og betydning omfatter andet og meget mere end elementer fra Grundtvigs arv.

En enkelt personlighed, Grundtvig, har gennem mere end hundrede år været og er stadig så dominerende i Danmark og en del steder i udlandet for forstålsen dels af 'det danske', dels af begreber som 'folk', 'folkelighed' og 'folkelige bevægelser', at det nyoprettede Centrum for Danmarksstudier ved Lunds universitet i 2001 afholdt en nordisk konference om fænomenet, hvis indlæg nu i 2003 foreligger med titlen, Grundtvig - nycklen till det danska?' ${ }^{1}$ Med rette stiller redaktørerne på 
flappen det retoriske spørgsmål, "nämn den svensk som skapat sådan debatt 130 år efter sin död!". Det centrale i bogens danske og svenske indlæg er belysning dels af sider af Grundtvigs åndelige og identitetsskabende virkningshistorie, dels af - men desværre mindre explicit udtrykt - hvorledes virkningshistorien rent konkret socialt udtrykkes gennem blandt andet de ældre folkelige bevægelsers arvtagere, fx i kirkeliv (Tidehverv) og i politik (Dansk Folkeparti). At forfatterne til bogen personligt ikke har megen sympati for disse nyere bevægelser og deres ledere og opfatter hævdelsen af arven og tankegodset i det folkelige fra Grundtvig mere som en voldtægt end en kærlighedsakt i forhold til den gamle, er så en anden sag.

Det væsentlige er her, at for disse kyndige iagttagere blandt bogens forfattere er det så selvfølgeligt, at det for ofte end ikke bliver nævnt, at Grundtvigs ord og meninger ikke spredes af sig selv, blot fordi de er trykt og måske en gang for hundrede år siden var med til at påvirke og ændre samfundet. Som jeg ser det, skal ethvert budskab og også Grundtvigs naturligvis læses, genfortolkes, spredes og på ny godtages som væsentligt i hver generation og for hver ny gruppe af mennesker ude i samfundet; ellers er der ikke nogen virkningshistorie, men kun det forbigangnes evige stilhed. Altså: nogen skal gøre noget for at sprede budskabet, ellers bliver det ikke hørt, og nogen skal gøre noget for at modtage det, ellers făr det ikke nogen bredere betydning - bortset fra hos en meget lille gruppe bogorme og blækhorn, for nu at tale grundtvigsk. Og disse engagerede 'nogen' og dette samfundsmæssigt aktiverende 'noget' er netop det organiserede åndelige, sociale og politiske røre i samfundslivet og det deraf skabte foreningsliv og de fastere institutioner (friskoler, blade, faglige organisationer mv.), som samlet udgør de folkelige bevagelser. 


\section{Kommentar til skema - folgende side}

Oversigt i skemaform over de vigtigste typer af folkelige bevægelser. Hver undergruppe i skemaet indeholder i sig selv ofte hundredvis, ja, tusindvis af foreninger og institutioner. Således var der omkring 1914 i alt 1253 Indre Missions lokalsamfund, hvis ca. 250,000 mennesker mødtes i lidt over 800 missionshuse, mens agrarsektorens landmænd samlet leverede mælk til ca. 1.400 andelsmejerier. I året 2003 var der ca. 11.000 selvstændige foreninger samlet under blot det ene af de to store kropskulturelle forbund, Dansk Idrats Forbund, jf. fx Jyllands Posten 9. 9 2003, 1, s 14. Danmark var og er stadigt 'ForeningsDanmark' med et ufatteligt stort antal foreninger dækkende snart sagt alle samfundslivets områder for individer og grupper og et kollektivt virke, der som oftest er udsprunget af eller har tilknytning til de folkelige bevægelser. Socialt set inddrager forenings- og organisationssystemerne $h ø j$ og lav, mænd og kvinder, unge og gamle - selv de sidste 30 års indvandrere har med et netværk af foreninger, muslimske skoler mv. taget denne del af 'Forenings-Danmark' til sig.

Tidsaksen for neden angiver omtrentligt året for bevægelsens eller foreningernes eller institutionernes gennemslag.

Agrar/urban-opdelingen i hver sit skema tager udgangspunkt i det empiriske faktum, at samfundsforholdene ca. 1800 til 1950 dels var meget forskellige mellem land og by, dels at København til efter 1900 var så selvstændig og stærk og omfattede omkring 1/4af den samlede befolkning, at hovedstaden helt dominerede urbansektoren. Modsat og ofte i bevidst opposition til hovedstaden havde agrarsektorens mennesker - og især gårdmændene - formået at skabe et eget system kulturelt ( $\mathrm{fx}$ højskoler), okonomisk ( $\mathrm{fx}$ andelsmejerier), politisk (fx Venstre), religiøst (Indre Mission og de grundtvigske) og i ungdomsarbejdet ( $\mathrm{fx}$ de grundtvigsk/venstre prægede ungdomsforeninger og Indre Missions KFUM og -K), selvom kropskulturen og fx KFUM og - K fik bredt gennemslag både på land og i by. Den skarpe agrar/urban adskillelse blev efter ca. 1920, blandt andet ved provins- og stationsbyernes vækst og vandringen fra land til by, mindre betydningsfuld, selvom ca. halvdelen af befolkningen på den tid endnu levede på landet og $\mathrm{i}$ de helt små bysamfund. Den agrart/urbane adskillelse mærkes stadigt omkring bevægelserne og foreningslivet helt op til 1960/70, dvs. til den tid, hvor agrar- og industrisamfundet afløstes af det postindustrielle uddannelses- og informationssamfund med nutidens stærkt ændrede livsformer, udvandede klassestrukturer, $90 \%$ kvinder ude på arbejdsmarkedet og kun 4-5\% af befolkningen beskæftiget ved landbruget mv.

Gyldighedsområdet for skemaet er tiden 1800 til 1960; men jeg har dog antydet to vigtige forhold vedrørende den sidste menneskealder: dels at det ældre foreningsnetværk og institutionssystem $\mathrm{i}$ høj grad har formået at tilpasse sig udviklingen med nye aktivitetsområder og derfor stadigt er levende eller er blevet genoplivet (fx mange forsamlingshuse), dels at nye enkeltsags-bevægelser med mere flade strukturer og kortere tidshorisont som sociale bevcegelser har opfanget og ofte med betydningsfuldt, samfundsmæssigt gennemslag har artikuleret kollektive $\emptyset$ nsker fra ganske mange i sagen engagerede mennesker. 


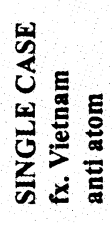

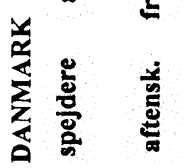

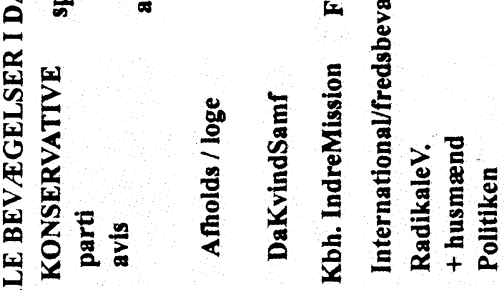

8

边范

응 홓

원종ㅎㅀ

초웛

인

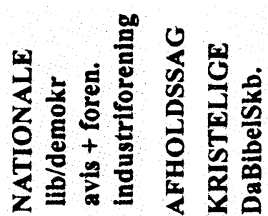

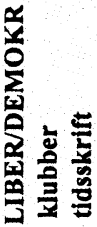

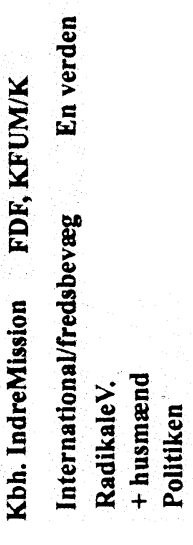

造

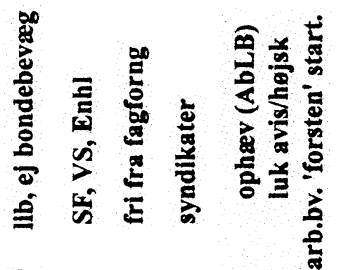

สิ

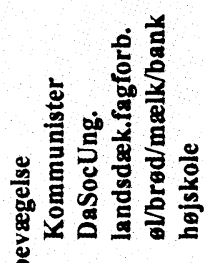

के 8

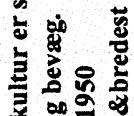

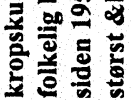
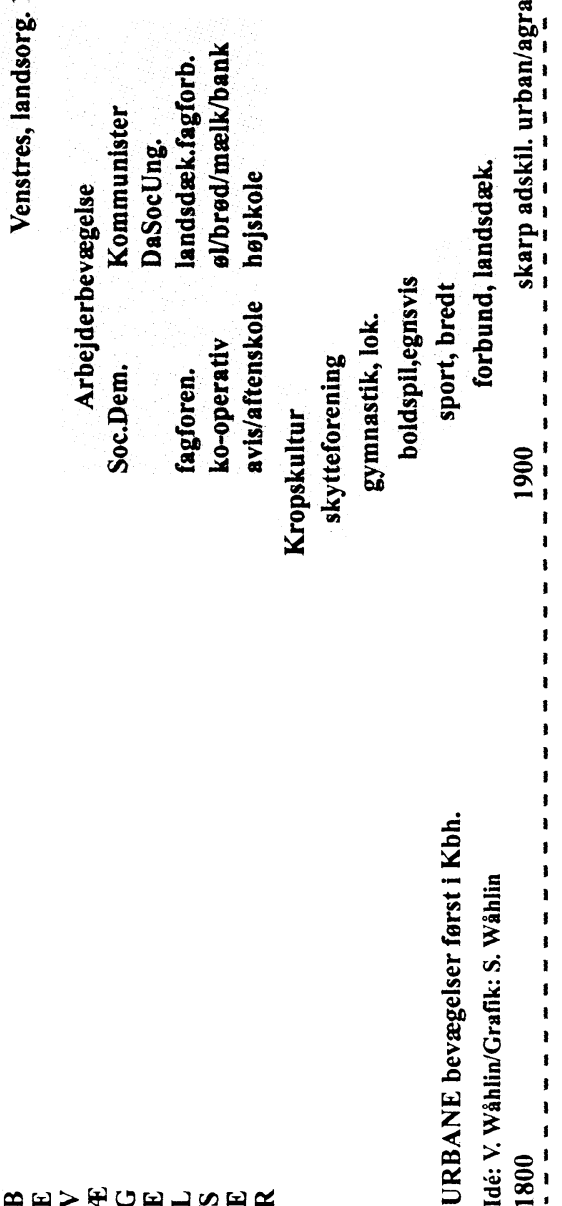


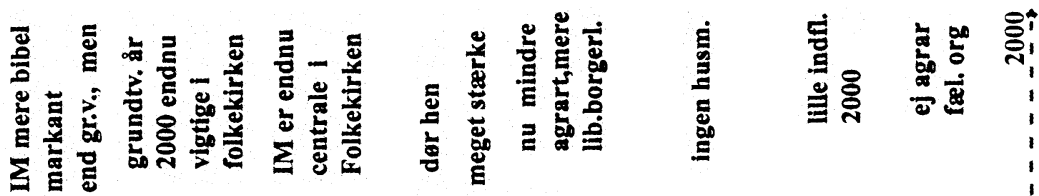

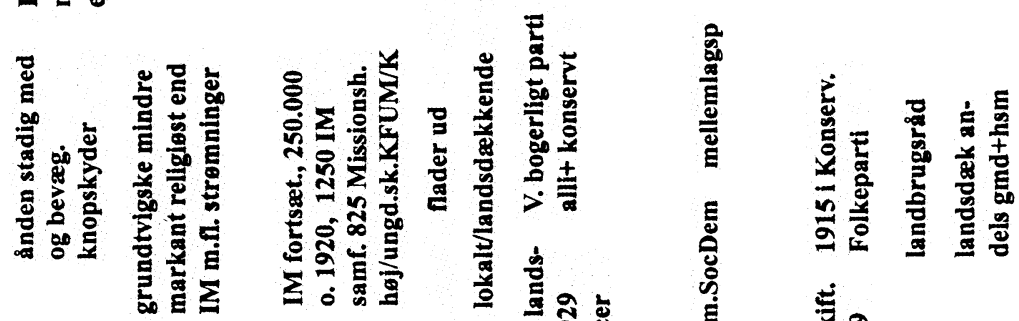

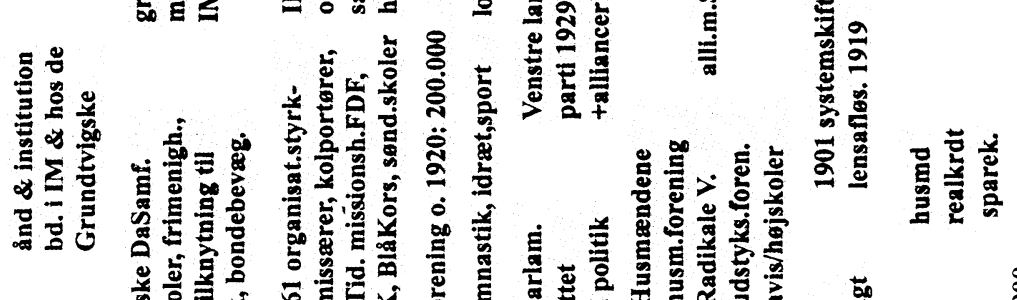

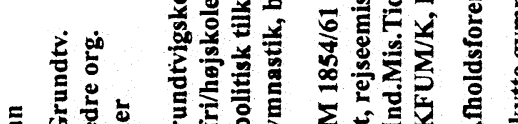

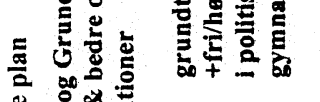
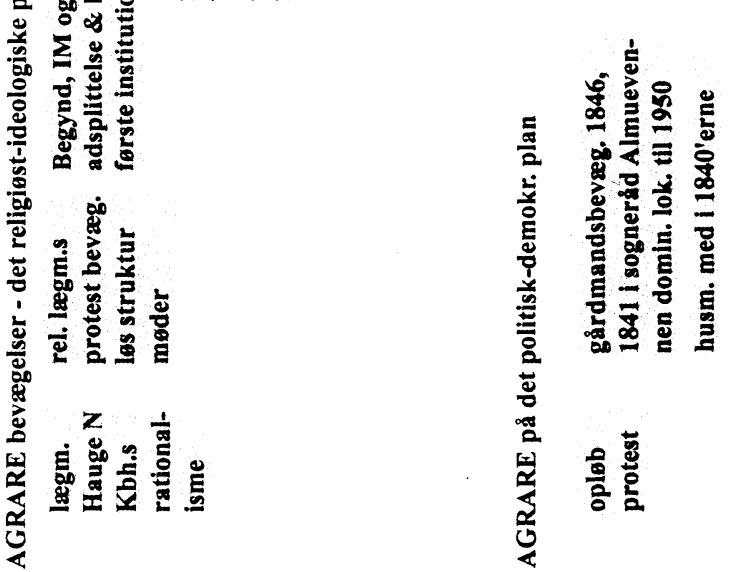
Enevaeldens rammer

\section{Foreninger og borgerlig optræden for 1848}

Enevældens politiske grundlov var Kongeloven af 1665 , og på tilsvarende vis virkede Danske Lov (DL) af 1683 som den juridiske ramme om dagligdagen for befolkningen. Herefter var det udtrykkeligt forbudt befolkningen offentligt at fremtræde $\mathrm{i}$ organiseret form med mindre sådanne forsamlinger eller møder var direkte tilladt eller fremtrådte mere tilfældigt efter gammel skik som, fx en maj-fest eller et bryllupsgilde, eller endog var direkte påbudt, fx som en menighed $\mathrm{i}$ kirken, en soldat $\mathrm{i}$ hæren eller som del af et håndværkerlav eller et landsbylav mv.

Det centrale var, at alle medlemmer af samfundet - undtagen kongen selv - i princippet var underlagt et pyramidisk kontrol- og tilsynsprincip, hvor de $\emptyset$ vre i systemet hele tiden var ansvarlige for de nedre: dvs. officeren for sine soldater, kaptajnen for sine matroser, mesteren for sine svende, husbonden for sit hushold og sit tyende, - og som det hedder $\mathrm{i}$ DL, bog VI, kap. 20, §2:

Om Professoribus (der skulle) have flittig Indseende med den studerende Ungdoms Exercitier, og holde den til Guds Frygt, Lydighed mod Øvrigheden, Ærbarhed, Skikkelighed, Fredsommelighed og Ædruelighed, og intet Usømmeligt som af dem begaais, lade Ustraffet bortgaa.

Der kunne også skabes fælles meninger og optræden på anden vis, fx gennem tryksager og opslag. Derfor var der også generel censur med alle tryksager til 1770'erne og fortsat om end mindre striks til 1849 mod især aviser og tidsskrifter, dvs. tryk under ca. 50 sider. End værre var det, om nogen søgte at skabe en offentlig stemning mod bestemte personer eller embedsmænd, hvorom DL,VI, kap. 21 bestemmer:

Overbeviser(s) nogen at have skrevet, eller opslaget, Skændskrifter og Pasqviller paa ærlige Folk, og haver ikke været sit Navn bekient, da bør hand miste sin Ære, og gaa i Jern sin Livs Tid paa Holmen, eller anden Stæde; Er det paa Øvrigheden, miste sin Hals.

Sådan! - den gang var der professormagt til og ingen anonyme evalueringsskemaer på universitetet, ligesom maling hældt over en minister den gang bogstaveligt bet $\varnothing \mathrm{d}$, 'af med hovedet'! 
I samme ånd udstedtes 1741 Konventikelplakaten imod en række netop da forekommende religiøse lægmandsmøder af pietistisk art. Bortset fra husandagter skulle præsten eller hans tilforordnede herefter tillade og eventuelt overvære gudelige forsamlinger af enhver art. 1741 bestemmelsen blev i begyndelsen af 1800-tallet ofte benyttet imod de gudelige forsamlinger, men brugen ophørte reelt o. 1840.

Supplikken var et direkte bønskrift til enevoldsherskeren eller et personligt fremmøde for mundtligt over for majestæten at fremføre en bøn eller klage. Den var et meget benyttet middel, dels blandt undersåtterne over for kongen, dels af denne til selv at læse og høre, hvad der rørte sig i befolkningen, og hvordan administrationen fungerede. Sådanne bønskrifter er bevaret i tusindvis, men er aldrig rigtigt blevet udnyttet $\mathrm{i}$ forskningen, skønt det af enkeltsager kan ses - og af kongemagtens gode rygte i befolkningen bekræftes - at supplikken faktisk fungerede som en trykventil over for folkelig utilfredshed.

Konstruktiv kritik, fra midten af 1700-tallet oprettedes af kongemagten eller med dennes billigelse flere selskaber, fx Det kgl. Danske Landhusholdningsselskab, med tidsskriftudgivelser mv. inden for selskabets lukkede kreds måtte der rimeligt frit diskuteres også kritisk om vigtige samfundsspørgsmål, blot retningen i kritikken ikke pegede direkte på majestæten, ligesom de styrende meget gerne så konkrete forbedringsforslag. Konstruktiv kritik og velbegrundede forslag i passende urban form fra en fremvoksende offentlighed var direkte ønsket af styret.

Offentlige tilkendegivelser - klap, hurra og pibekoncerter - under $\mathrm{fx}$ Det Kongelige Teaters forestillinger kunne under den sene enevælde fungere som udtryk for en offentlig mening, ligesom bøger med en seriøs fremlæggelsesform ofte blev inddraget $i$ en tidlig offemtlig debat. Generalforsamlingerne i påbudte organisationer som Hovedstadens Brandkasse mfl. blev benyttet til at udforme en offentlig mening om samfundets forhold, ligesom de pæne borgeres samtaler på respektable kaffehuse havde en tilsvarende funktion sidst i 1700-tallet og først i 1800-årene.

Klubberne, det var dog først med de borgerlige klubbers fremvækst i København efter engelsk og hollandsk forbillede fra 1770'erne, at et egentlig moderne diskussionsforum blev etableret. Tager vi antallet og velstanden $\mathrm{i}$ betragtning, som fandtes i København den gang, så kunne næppe mere end 5.000 mænd have tid og råd til at være med i de nye klubber og regnes som flittige læsere af det stigende antal tidsskrifter og aviser. Ad anden vej kan vi skønne, at mellem 1.000 og 2.000 faktisk har været aktivt med i klublivet, - set i forhold til 5.000 potentielle med- 
lemmer var der tale om en høj deltagerprocent. Ud fra enevældens natur måtte det være klart, at styret ønskede både formel og uformel kontrol og indsigt med dette nye forum for en offentlighed - det sidste skete blandt andet ved spioner, hvorom en samtidig siger: “ (...) da Øretudere og Spytslikkere dels lobe med, hvad der paa saadanne Steder kunde vare sagt og sket (...) ", hvorfor klubben måtte lukke dørene for ikke-medlemmer. Den offentlige kontrol sikredes, ved at foreningslivet ordnedes i 1780 med et reglement. Alle klubber og foreninger skulle herefter anmeldes til politiet med fremlæggelse af love og især anføre hvem, der som bestyrelse og formænd stod i spidsen og derfor kunne gøres ansvarlige for alt uønsket, som måtte hænde. Altså ikke noget forbud, men kontrol og igen med det pyramidiske ansvarsprincip fastslået.

Politisk organisering, studenterne - og senere de liberale - benyttede i 1820 vedrørende stiftelse af Studenterforeningen i København den anførte model for klubberne med angivelse af at ville skabe et primært videnskabeligt og æstetisk debatforum. Myndighederne gennemskuede klart det bagved liggende politiske formål om at skabe et akademisk, politisk offentlighedsrum, men statsmagten tillod alligevel oprettelsen af Studenterforeningen ud fra det synspunkt, at så var det nemmere ved spioner at holde $\varnothing j \mathrm{je}$ med, hvad der foregik. I 1831 fik derimod den venstreradikale artilleri-kaptajn C. F. Tscherning afslag på at oprette en i det ydre tilsvarende pæn diskussionsklub, '28. Maj Selskabet', netop med henvisning til det politiserende element i foreningen. I stedet arrangerede Tscherning og hans kreds gennem en årrække nogle vel besøgte offentlige festmiddage med taler og sange, som myndighederne lod passere. På tilsvarende vis fik de skandinaviske kræfter o. 1840, nej, til en foreningsdannelse, men da de havde udskiftet de mest politisk kontroversielle i bestyrelsen, blev foreningsdannelsen, under let ændret navn, tilladt.

Stcenderforsamlinger, efter juli-revolutionen i Frankrig blev regeringen presset til at indføre rådgivende stænderforsamlinger fra 1834 med de første møder i 1835 og 36 ff. I både Københavns klubber og foreninger samt i aviserne førte valgene til en øget politisering, hvis 'skrivefrækhed' irriterede Frederik VI, så han påtænkte en stramning af trykkelovgivningen. Dette fik det moderate, liberale borgerskab både $\mathrm{i}$ København og i provinsbyerne op af stolene, og på kort tid havde man fået etableret landets første masseorganisation Selskabet til Trykkefrihedens rette Brug. Trykkefrihedsselskabet fungerede derefter som en fra begge sider stilfærdigt anerkendt buffer mellem styret og de mere rabiate pressefolk og liberalister. 
Underklassens vrede, således kunne det dannede borgerskab finde en balance mellem enevælde og en offentlig udtrykt frihedstrang. Men dybere i folkehavet blandt $\varnothing$ konomisk klemte småborgere og proletariserede, arbejdsløse svende brusede vreden og den dybe sociale utilfredshed. Denne blev igen og igen om natten udtrykt på opslåede plakater på byens mure - som politiet om morgenen ligeså flittigt pillede ned igen og gemte $i$ arkivet $-f x$ sålydende:

Konge vil du undgaae Folkets Fortvivlelse og Raserie, da sørg for Beskieftigelse for Folket, og Næringsgrenenes Oplivelse, (...) førend det er for sildig! Wiid Konge! at du er for Folket!!! og Folket ikke for dig.

(Eller om andre klassespændinger fra en anden pasquille fra politiarkivet, fra sidst i 1830 'erne):

[skriv dog om] den nederdrægtige og Pøbelagtige Opførsel som de danske Studenter har vist i Naboriget. (...) [de fylder sig i brændevinshusene og jager liderligt efter skørterne og] Komme om Natten, vel og om Dagen, sprøjtefulde hjem i Logiet, slaae alt istykker, gjør Svineri og bedrage Verterne for Huusleien. Alt dette er den rene Sandhed og ingen Løgn. Og disse Mennesker vil regjere Land og Rige!

By-borgerlige bevagelser, når de unge liberale akademikere i 1830'ernes og 1840'ernes borgerlige bevægelser talte så varmt om 'folket' og 'friheden', var det dog næppe disse plakatskrivere og de andre titusinder i de lavere sociallag, de tænkte på, men nok snarere sig selv.

Det centrale er, at årtier tidligere, end de gudelige forsamlinger på landet bredte sig, var det københavnske borgerskab, stadens småborgere og de unge akademikere trukket ind $\mathrm{i}$ og vel bekendte med både udtryksformer og virkemåder for en ideologisk og politisk offentlighed og for en organisatorisk effektiv fremtræden. - At grundloven og demokratiet kom allerede i 1849 havde sin anledning i krigen 1848-50, men den egentlige årsag fandtes forud i to hovedforhold: forst, den midlertidige alliance mellem en politiseret gårdmandsstand og den liberale bevægelse i Bondevennernes Selskab af 1846, dernaest, det liberale borgerskab i København var klar til at vippe enevælden og overtage magten. $^{2}$ 
Fra statspatriotisme til nationale bevagelser

\section{Tysk og dansk i stigende modsæetning}

Absolutismen var af princip ikke national i moderne forstand, men knyttede meget ofte dygtige udlændinge til sig, som ikke havde rod og loyalitet for stærkt knyttet til nogen af konglomeratstatens (sam-statens) nationale eller klassemæssige befolkningsgrupper. Indfødsretsloven af 1776 danner således en overgang til en patriotisk patriarkalisme, hvor statsloyalitet $\emptyset$ nskedes knyttet til, at embedsstanden var født i og følte sig som en del af kongens riger og lande. Men om embedsmandens hjemmesprog var tysk, dansk, norsk, islandsk, plattysk, frisisk eller engelsk ( $\mathrm{fx}$ Vestindien) var i den sammenhæng mindre vigtigt - de officielle sprog for styret var dansk og tysk.

Begyndende i Holsten i de første årtier af 1800-tallet og snart bredende sig til Slesvigs overklasse og by-borgerskab fremvoksede, blandt andet med baggrund i eftervirkningerne af Napoleonskrigene, en stigende bevidsthed om og hævdelse af en tyskhed og af tysk kulturel og historisk forrang i hertugdømmerne. Disse tendenser blev fremmet af blandt andet centralregeringens krav om dansk som ligestillet sprog, $\mathrm{fx}$ ved offentliggørelse af alle love og forordninger parallelt på dansk og tysk i Slesvig.

Det holstenske ridderskab havde fra lang tid tilbage sin egen interesserepræsentation, som om end tøvende knyttede an til de voksende tysk-nationalt borgerlige strømninger, der blandt andet fandtes på universitetet i Kiel. Ridderskabets klassemæssige foragt for de liberaltborgerlige tendenser blev dog langsomt overvundet af de økonomiske og klassemæssige fællesinteresser med storgodsejerne i Slesvig. Men først da de magtfrustrerede hertugelige augustenborgere legitimerede den tyske og senere den Slesvig-Holstenske sag, kom det fornuftsægteskab i stand mellem godsejer-adel og tysk national-liberalt borgerskab, som med en bred offentlig støtte i Tyskland fra 1830'erne og fremad skabte baggrund for et egentligt opgør med Danmarks århundredlange politiske dominans i samstaten.

Anledningen til opg øret og borgerkrigen $1848-50 \mathrm{blev}$ dansk-nationale politiske manifestationer i Slesvigs stænderforsamling i 1840'erne og andre steder, men årsagen lå langt dybere: forst i Danmarks småstatssårbarhed efter tabet af Norge 1814, dernoest i europæisk nationale strømninger, som blandt andet Preussen i pangermansk regi havde 
spændt for sin aggressive udenrigspolitiks vogn omkring 1840 og endeligt i de danske liberales dobbelte erkendelse af dels deres egen svaghed efter 1839 over for Chr. VIII's intelligente udnyttelse af den rodfæstede enevælde, dels den folkelige styrke og appel i et dansknationalt program, - og følgelig blev de næsten over nat i 1842 fra liberale til de national-liberale, Danmarks første politiske parti. De havde gennem en national danskhed endelig fået en sag med folkelig appel, der kunne bruges i deres politiske kamp og stræben efter magten. Men selv med denne sag på banneret kunne de ikke overvinde enevælden undtagen i en alliance med den nye middelklasse på landet, gårdmoendene, hvilket endeligt lykkedes for en del liberale i 1846 med dannelsen af Bondevennernes Selskab med snart langt over 5.000 medlemmer.

\section{Folk og danskhed - en handlingsbestem mende virkelighed}

Folkemøderne af national-patriotisk art i 1840'erne begyndte med Steen Steensen Blichers Himmelbjerg-fester, som snart trak flere tusinde tilhørere. På Skamlingsbanke-møderne fra 1843 blev den dansk-nationale og dermed anti-Slesvig-Holstenske linie trukket skarpere op bl.a af Grundtvig som hovedtaler.

Den herskende patriotisk-statslige linie og stemning i ledende kredse fra 1770'erne og fremad - underst $\varnothing$ ttet af bondebefolkningens gammeldags kongetroskab - blev i finkulturen fra de første år af 1800-tallet suppleret med en europæisk påvirket national-romantisk, men bevidst dansk tendens med borgerlig idyl og hjemlig hygge. Folket i sagn og klædedragt, i historie og landskab, i hverdag og fest blev opdaget og opfundet af malere og komponister, af digtere og folkelivsforskere $\mathrm{mfl}$., men blev i særlig grad givet liv og form af N.F.S. Grundtvig. I prosa og sang, i politik og polemik, i tale og på skrift formåede Grundtvig gennem årene at forene kristelige og nationale, historiske og kulturelle, landskabelige og sproglige tilgange og udtryk til en mangefacetteret helhedsforståelse af dette mærkelige kollektive begreb, det danske folk.

Hverken det danske eller folket kunne eller kan defineres i logiske eller rationelt tilfredsstillende termer - hvorfor mange af nutidens akademikere og forskere bortskaffer fænomenet ved frejdigt at erklære dets logiske og sociale ikke-eksistens og med Benedict Anderssons, Imagined Communities (London, 1983, sv. overs. Stockholm,1996) henviser det til en blot imaginær eller rent forestillet sfære. Omvendt vil jeg i overensstemmelse med fortidige og nutidige historiske fakta fortsat hævde, at ord dræber og drømme virkeliggøres som menneskenes kollektive sociale 
handlinger, der skaber sociale og materielle virkeligheder - hvad enten vi i dag anser dem for tilbagegang, stilstand eller fremskridt - som fx det danske og det folkelige. Nye generationer vil drømme nye drømme i nye fællesskaber, hvori drømmene bliver til ord, og ordene skaber, hvad de nævner - og træet skal kendes på sine frugter.

I det førmoderne samfunds stænderstat var befolkningen, som hver sin stand, splittet op i bønder (almue), adelige, borgere og præsteskab, mens helheden af disse frem til den sene enevælde defineredes som kongens loyale undersåtter og ikke som danske, norske eller tyske. Trods rødder tilbage til middelalderen, forstået ud fra modsatningen til især svensk eller tysk eller fransk eller latin, ${ }^{3}$ så fremstod folket (som noget andet end befolkningen) og det danske i moderne forstand først sidst i 1700-tallet og udbredtes til mange i 1800-tallet for at blive en fremherskende strømning i 1900-tallet. Heri er jeg langt hen enig, men det betyder aldeles ikke, at danskhed og folket, det vil sige dansk nationalfølelse, derfor med postmodernismen i den sidste menneskealder er eller skulle være et overstået stade mentalitets- og bevidsthedshistorisk set - som en slags smålatterlig kollektiv pubertetsforelskelse.

For mig at se ud fra dels det nye årtusindes $y d r e$ nationalt og nationalistisk manifesterede virkelighed fra Balkan til Rusland mv., dels den indre danske skepsis i brede befolkningslag over for EU og globaliseringen, så $\mathrm{d} \emptyset \mathrm{r}$ det danske og folket først bort, når eller hvis disse udefinerlige mentale og sociale virkeligheder om folk og nationalitet $i k k e$ langere i og for enkeltmennesket og i og for dettes fællesskab i ord og gerning bliver tilvalgt og forsvaret og stadig gentilegnet og fornyet. Det nationale - modsat den enøjede nationalisme - blev og er en identitetsskabende måde at se og forstå og udtrykke jeg'et, samfundet og verden på parallelt til religionen eller kunsten eller klasse- og kønstilhørsforholdet som fortolkningsrammer. Ser vi på mængden af dagens etniske og statslige konflikter, er der ikke meget, som tyder på, at det nationale og folkelige aspekt er et overstået stadium i historiens gang. I den forstand er den nationale tilgang en løbende folkeafstemning om tilhørsforhold såvel i den enkelte som kollektivt og med ganske alvorlige følger for den enkelte og samfundet $i$ handlingernes og virkelighedens verden. Omvendt er det lige så oplagt, at mange - måske et flertal - af den internationalt orienterede, flersprogede, normsættende og kulturforandringsåbne elite af i dag blandt politikere, organisationsledere, forretningsfolk og akademikere må se det nationale, det vil sige in casu folk og danskhed, som en indsnævring eller direkte hindring i forhold til deres omverdensforståelse og som en spændetrøje for deres udfoldelsesmuligheder. Altså sådan på 
linie med, hvordan internationale kapitalister for 100 år siden så på industriarbejdernes klasseselvforsvar, adelen for 300 år siden så på bøndernes snævre lokalhorisont og kirkens mænd i middelalderen ud fra latinens og kirkens fællesskab så på de ulærdes smalle dannelsesbaggrund. I den ny tid er det - som i gamle dage - dem uden penge, uden højere udannelse, uden flersproglighed og i dag uden IT-nemme, som skal betale regningen for globaliseringen. Den slags er stadigt (og hedder på dansk klassekamp) rettet fra samfundets elite imod befolkningens brede lag - om end med et mere menneskeligt ansigt end fortidens ret åbenlyse og ofte ganske brutale undertrykkelser.

Det nationale blev i anførte forstand, dvs. folket og det danske, gennem 1800-tallet et led i hele Danmarks og folkets selvforståelse og historie, som en grundtone, der også trængte gennem flere af de andre bevægelser med et eller andet erklæret formål, og som i disse år satte noget i svingninger. Indre Missions høvding Vilh. Beck fastholdt således i mange år forrangen for 'troen til frelse', som det ene fornødne, der over dagens og landets politik kunne og skulle binde mennesker sammen i et større, kristent fællesskab; men også han måtte dog sidst i 1890'erne offentligt vedkende sig sin danskhed. J. Skjoldborgs husmandssange fra begyndelsen af 1900-tallet har ikke statsmagten eller flaget eller den fælles historie som nationalitetsbærende og identitetsskabende symboler, men derimod det hårde arbejde $\mathrm{i}$ det danske landskab, det skiftende vejrlig og drømmen om en beskeden bid af den danske jord - og ikke om en farm i Amerika - som det bærende. Socialismen som ideologi var international, men arbejderbevægelsen og dens socialdemokratiske ledere her i landet blev omkring Første Verdenskrig nationale og samfundsbærende og kunne med Oscar Hansens meget populære sang (1934) snart samles under slagord som:

(...) den nye Folkets Tid.

Plads for dem alle,

Plads for alle, der vil:

Danmark for. Folket!

Der er her ikke som i den ældre arbejderbevægelse tale om 'Sultens Slavehær' eller 'Arbejdernes Tidsalder', men om Folkets Tid, ikke om revolution, men om samarbejde med alle, som vil det fælles bedste i et Danmark for Folket - hvor arbejdere og bønder, kontorfolk og intellektuelle, mænd og kvinder trækker på samme hammel, hvor folk og land er 
blevet ét. De kølige hjerner skal her erindre, at sangen er skrevet midt under den $\varnothing$ konomiske verdenskrise og lige efter Kanslergadeforliget (1933), hvor Venstres gårdmænd, de Radikales husmænd og Socialdemokratiets arbejdere indgik Danmarkshistoriens indtil da største historiske aftale om landbrugsregulering og socialreform - af mange iagttagere set som den moderne velfærdsstats grundlæggelse og det samarbejdende folkestyres største sejr, men af andre tolket som det endegyldige klasseforræderi.

Hvordan relationen mellem hjemstavn og lokalpatriotisme er i forhold til den nationale dimension og til det enkelte menneskes oplevelsessfære, må vi her lade ligge. Men, fx regionalismen i Slesvig synes lige så grundfæstet som det nationale aspekt i kampen om Sønderjylland, og opblomstringen siden 1970 af interessen for lokalhistorien står overordentligt stærkt. $^{+}$

\section{Folk og nation, identitetsskabelse og vardigrundlag - sammenfatning}

Nationalitet, dvs. det nationale forstået som en kollektiv og følelsesladet bevidsthed om fædreland og fællesskab eksisterer ikke og kan ikke være uden et

- folk til at bære denne bevidsthed, rumme dette fællesskab og i handlinger realisere dette, hvilket igen kun har mening og realhistorisk eksistens manifesteret i geografisk rum og i tid og i sprog inden for et givet landområde med tilhørende natur og vejrlig, in casu

- Danmark, der i egen selvforståelse og af andre lande var og er anerkendt som sådant og havde og har en egen tidskontinuerlig, sammenknyttende

- historie, selvom denne kan være både mytisk og uvidenskabelig og stærkt betvivlet af andre, fx svenske og tyske, og et

- falles sprog, dansk, hvori den enkelte og fællesskabet kunne og kan tænke og udtrykke sig indbyrdes $i$ et fælles skriftsprog og en fælles forståelig tale - med al respekt for dialekterne - i poesi, retsvæsen, politik, dagligliv osv. og med alle menneskelivets

- kulturelle og religiose udtryksformer i skikke og vaner, fra fødsel til $\mathrm{d} ø \mathrm{~d}$, i fest og arbejdsliv, for unge og gamle tydeligt genkendelige og bredt accepteret ud fra et stadigt diskuteret, men dog falles værdigrundlag.

Imidlertid var og er folk og danskhed nok karakteriseret af og historisk begrundet i disse samt en del mindre centrale begreber. Men hvis folk og danskhed skulle og skal gå op i en højere enhed, så må danskeren godtage 
og som samfundsmedlem aktivt virke for disse begrebers opretholdelse, udbredelse og realisering, dvs. danskeren må have dem ikke blot som ydre kendetegn, men må indoptage eller inderliggøre dem som en uadskillelig del af sig selv og sin måde at være menneske på.

Herved flyttes forståelsen fra et ydre iagttageligt program for selvforståelse til en kvalitativ livsholdningstilegnelse; det at være en del af det danske folk i denne forståelse var og er ikke blot at have pas og statsborgerskab samt at følge lovene og de ydre spilleregler, men nok så meget at leve med, føle for og aktivt virke $i$ dette kvalitative værdifællesskab - enhver efter evne og mulighed.

Dette var så noget om den historiske baggrund for og den kvalitative forståelse af folk og danskhed, der både indgår i og samfundsmæssigt udfoldes gennem de folkelige bevægelser.

\section{Sociale og folkelige bevagelser - en begrebsafklaring}

I en række angelsaksisk inspireręde samfundsfaglige og sociologiske forståelser tales der ret konsekvent om 'sociale bevægelser' forstået som samspillet mellem omfattende mentale strømninger og tilsvarende kollektive handlingsmønstre i bredere samfundslag foranlediget af og primært rettet imod bestemte og som oftest nyligt opståede samfundsmæssige forhold og forståelser deraf, altså en slags protestbevægelser. Disse beskrives som generelt havende en flad struktur og ringe organisatorisk fasthed i tilhængerskaren og er som samfundsmæssig forandrende kraft af relativ kortvarig betydning. Men de kan i de korte tidsspand ved slagkraftige aktioner opnå stor opmærksomhed i medierne og have varig betydning især for de engagerede deltageres videre liv. For eksempel må herhjemme og bredt i den vestlige verden anti-atomkraft bevægelsen fra 1970'erne og anti-Vietnam-krigs-røret anses for sådanne sociale bevægelse. ${ }^{5}$

Det særligt i Danmark og delvist i Norden anvendte begreb folkelige bevægelser - eller tidligere 'folkebevægelser' - hænger som ovenfor vist sammen med en kvalitativ forståelse af begrebet 'folk', således at ikke alle sociale eller ideologiske bevægelser, selvom de måske kan blive det, $\mathrm{i}$ sig selv var eller er folkelige bevægelser. I overensstemmelse med romantikkens folkebegreb, hvor folket i sig indeholder og er sig enkeltvis og i fællesskab bevidst om inden for et givet geografisk område, et land, at have og være bærer af en fælles historie, et fælles sprog, en fælles kultur - og herunder et samspil med og en glæde over landets natur - er 'folk' ikke noget, der blot forefindes eller er. Det kvalitative begreb, et 
folk med et klart kendemærke, her som dansk, er noget den enkelte og fællesskabet delvist har en mere ustruktureret anelse om, men, når anelsen bliver bevidst, i en livslang, ja, århundrede lang proces kæmper for at blive og i yderste ende vil forsvare selv med livet som indsats. ${ }^{6}$

For Grundtvig fremstod gårdmænd, husmænd $\mathrm{og}$ håndværkere som den sunde, samfundsmæssige kerne, der gennem et langstrakt opvågningsforløb og hjulpet på vej, fx gennem en højskole, burde og kunne blive det danske folk ved at påtage sig et nationalt og samfundsmæssigt ansvar. Det nye industriarbejderproletariat, som Grundtvig især havde iagttaget i England, men også havde fundet på Københavns skibsværfter, var for ham ofte menneskeligt fornedret og ført bort fra og ud af denne mulighed som ansvarlige samfundsmedlemmer, og borgerskabet og akademikerne i København var ikke, men kunne måske med tiden blive en positiv del af dette kvalitative 'folk'?

\section{Gårdmænd, husmænd, arbejdere og folkelige bevægelser}

Man har blandt historikere ofte talt om 'bondebevægelsen' forstået som den gamle agrare almues stigende involvering fra 1840 'erne i samfundsanliggenderne til forsvar af egne interesser og ofte agerende bevidst mod dominansen på landsplan og lokalt dels fra byerne og især København, dels mere klassemæssigt mod indflydelsen fra på den ene side akademikere, embedsborgerskab og det økonomiske storborgerskab og på den anden side fra godsejerne. Skønt nogle få husmænd gjorde sig stærkt bemærket i dette røres tidlige år, så var der reelt op til omkring 1900 tale om forskellige grene af bevægelser blandt gårdmoendene lokalt og mere landsdækkende: forst religiøst-kulturelt, politisk, nationalt-dansk (fremmet af krigene 1848-50 og 1864) og økonomisk-finansielt (forsikring, kreditforeninger, sparekasser), senere kulturelt-oplysningsmæssigt (højskolerne, friskolerne, venstre-pressen fra 1860'erne og forsamlingshusene og missionshusene fra 1880'erne) og endelig fra 1880'erne økonomiskproduktionsmæssigt med hele andelsbevægelsen og økonomisk-distributionsmæssigt med brugsforeningerne.

Husmændene fulgte først for alvor fra $0.1900 \mathrm{i}$ gårdmændenes spor med ideologiske og organisationsmæssige samt $\varnothing$ konomiske og politiske tiltag til forsvar for og udvidelse af egne samfundsmæssige interesser. Ved en heldig alliance med visse grupper af skolelærere og akademikere gik husmændene politisk og nu som bevidst samfundsbærende sociallag fra 1905 fra at være organiserede særinteresser til at blive en folkelig bevægelse i mere kvalitativ forstand. 
De urbant-industrielle arbejdere og den med tiden voksende funktionærklasse tilkæmpede sig og organiserede arbejdernes og lønmodtagernes kollektive potentiale i København fra 1880'erne og siden fra o. 1900 ud over landet gennem fagbevægelsen og Socialdemokratiet samt en arbejderpresse og mange kooperative virksomheder. Først på det lokale plan og siden landsdækkende blev arbejderne som bevægelse samfundsbærende og samfundsforandrende i anførte forstand fra efter 1920. Noget sådant lå naturligvis uden for selv en Grundtvigs vidsyn at omfatte. ${ }^{8}$ Senest fra o. Første Verdenskrig var arbejderbevægelsen i denne socialt konstruktive og brede forstand en folkelig bevagelse - men set fra en revolutionær synsvinkel altså samtidigt forrædere mod proletariatets revolution.

\section{Sociale bevægelser som protestudtryk}

En social protest som urolighederne over brødpriserne i København 1847/48, gentagne opløb som jøde-urolighederne i Danmark o. 1820, maskinstormerne blandt engelske tekstilarbejdere o. 1800 eller antiatomkraft bevægelsen fra 1970'erne var nok kollektive udtryk for fælles vrede og kunne være ganske alvorlige i tiden; men de havde ikke i sig noget fremadrettet konstruktivt samfundsforandrende perspektiv. ${ }^{9}$ De var derfor sociale eller ideologiske protestbevægelser, men ikke folkelige bevægelser i ovenanførte kvalitative forstand. Dertil manglede de en bredere samfundsdannende og samfundsbærende udfoldelsesretning og en fælles vilje udtrykt over længere tidsspand og med evne til at fastholde og inddrage andet end helt snævre kredse og interesser.

Blandt andet fordi institutioner og faste organisationer afkaster meget og brugbart kildemateriale, som ofte lader sig datalogisk behandle, har der i samfundsvidenskaberne op til de allerseneste år og blandt forskerne i almindelighed været en tendens til at overfortolke den historiske og samtidige betydning af institutioner og organisationer som bærere af social og institutionel 'magt'. Der har modsvarende været en tendens til at underkende betydningen af de mere bløde kulturelle og mentalitetshistoriske aspekter af individuelle og kollektive livsholdninger, overbevisninger, ideologier og religiøse opfattelser, som ofte har fundet udtryk i de folkelige bevægelser. Denne 'hårde' holdning i samfunds- og historievidenskab vedrørende den sociale og kulturelle virkelighed og ved valget af interessante forskningsfelter og strategier er fra o. 1990 afgørende på tilbagetog i forhold til en mere kompleks og multivariabel tilgang. ${ }^{10}$ 
Fig. I - Folkelige bevægelser

Signaturforklaring

M: Organiseret og indkaldt møde

I: Institution

IM: Bevægelse, Indre Mission

Grundtv.: Bevægelse, Grundtvigianisme

F: Fagforening

A: Andelsbevægelse og kooperation

Sk.: Skole

F.hus: Forsamlingshus og missionshus

Ung.: Ungdomsorganisationer

Sport: Gymnastik- og sportsforeninger

Spr.k.: Sparekasse

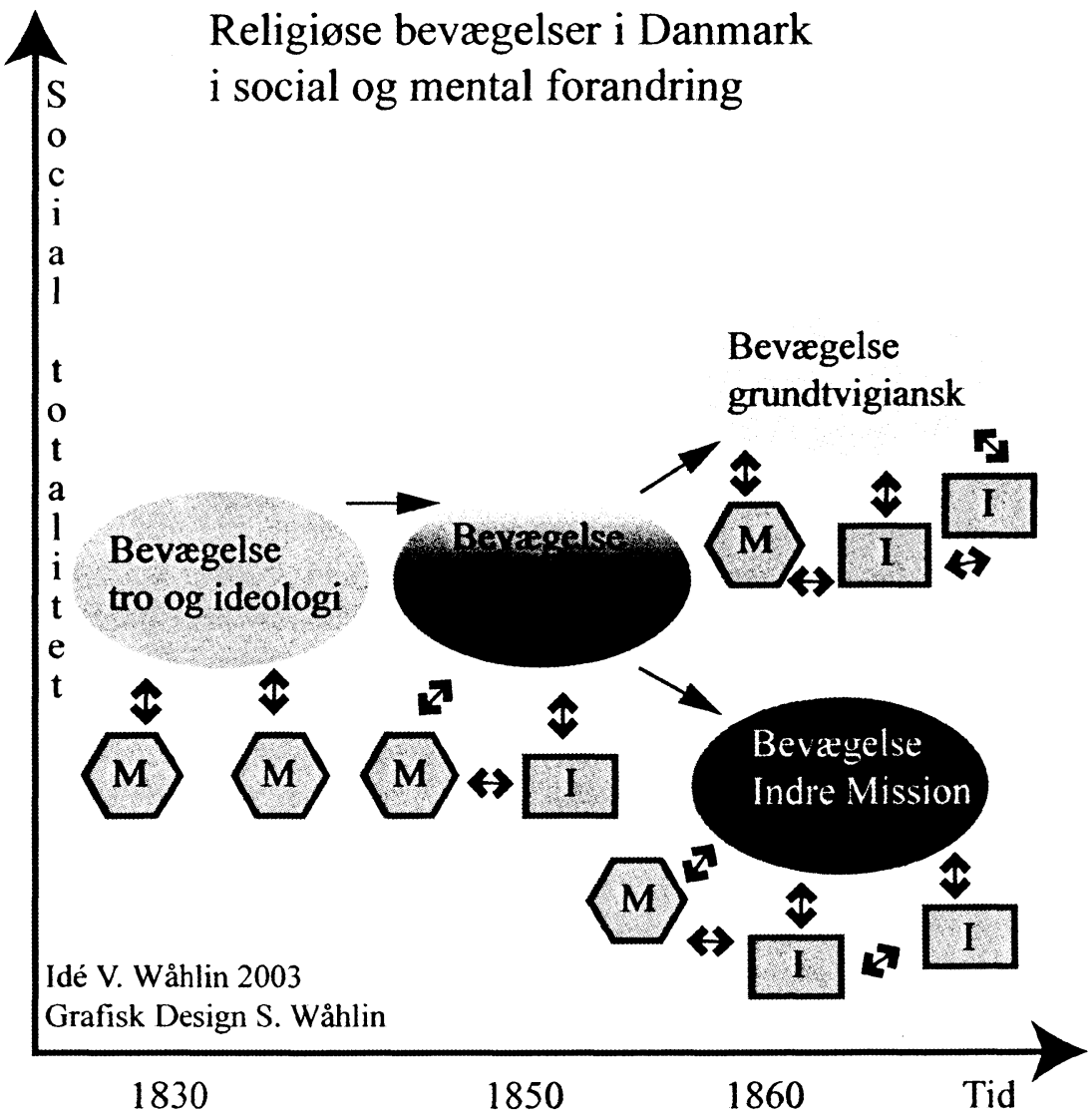



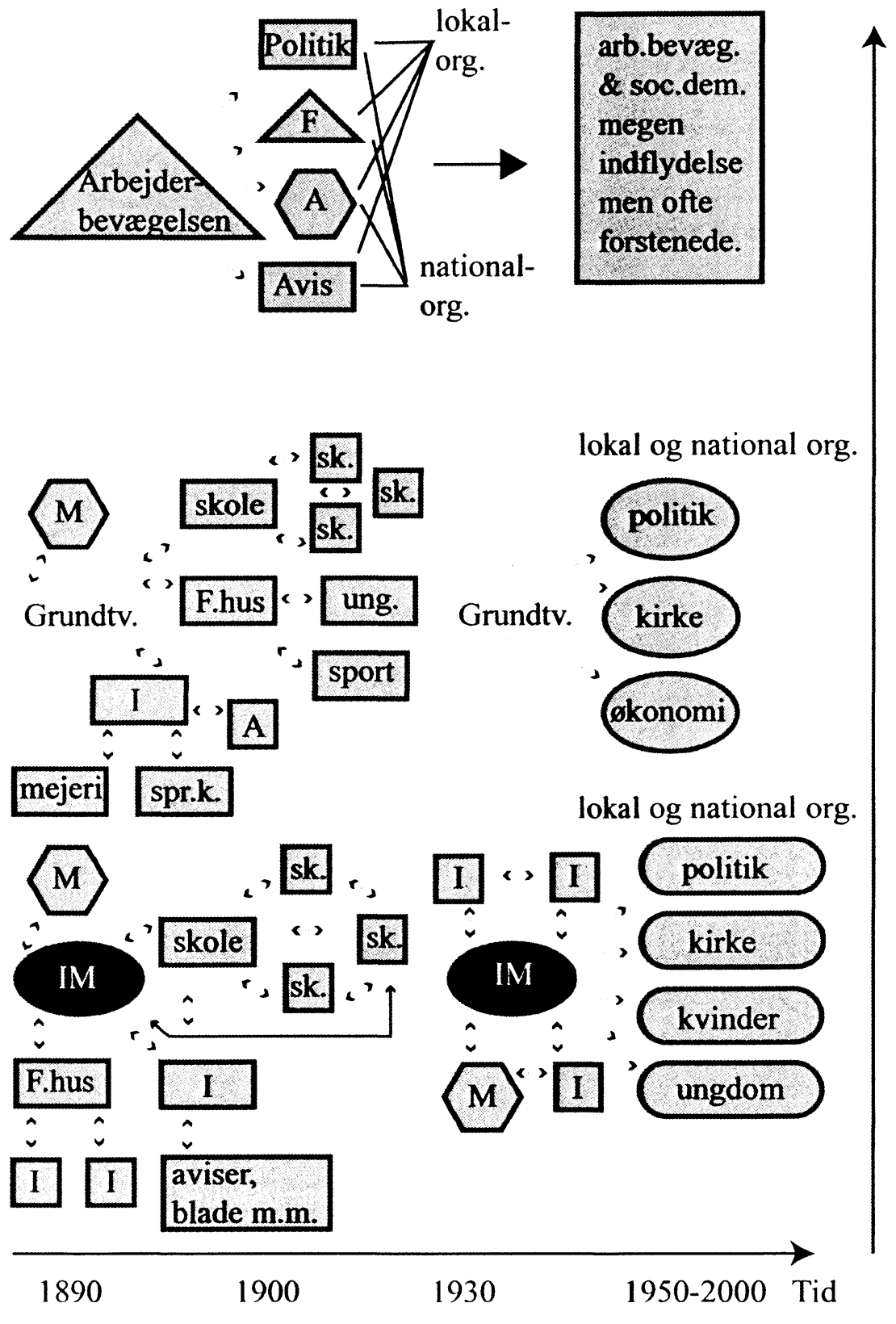


\section{Kommentar til Fig. I.}

Tidslinien fra 0.1800 løber fra venstre tværs over de to sider til o. år 2000 .

Tre bevagelser: i idealtypisk forstand aftegnes de i Danmark tre væsentlige folkelige bevægelser (og med en fase I til de første o. 1820): de grundtvigske, Indre Mission og arbejderbevægelsen - mens andre bevægelser for klarhedens skyld bevidst her er udeladt, men ofte følger samme mønster, jf. skema ovenfor. Alle bevagelser er gengivet med deres organisatoriske og institutionelle afkast indtegnet som cirkler, ovaler, firkanter, rektangler, trekanter mv. i et netværk i fase II fra o. 1860, ligesom den antydede indre splittelse blandt de religiøse allerede fandtes før 1850 .

Knopskydning, fra o. 1880/90, med fase III, afkaster næsten alle foreninger og institutioner ved en slags knopskydning igen nye underorganisationer ( $\mathrm{fx}$ kvindeforeninger, ungdomsarbejde $\mathrm{mv}$.) og institutioner ( $\mathrm{fx}$ friskoler fra højskoler, spejdere fra KFUM mv.).

De religiose bevægelser fortsætter deres løse og ustrukturerede form ( $\mathrm{fx}$ findes intet medlemsregister) med hovedvægten på den ideologisk inspirerende dimension og stadigt til o. 1900 med et dominerende virke i agrarsektoren, mens det praktiske arbejde udføres i organisationer og institutioner - fra 0.1890 slår IM igennem i Københavns arbejderkvarterer.

Arbejderbevagelsen (bl.a. på grund af samfundets større modtryk økonomisk og politisk) er i modsætning til de religiøse og med hovedvægt i urbansektoren næsten fra begyndelsen fastere organiseret lokalt og nationalt: fagligt $\mathrm{i}$ fagforeninger, politisk i Socialdemokratiet, kulturelt omkring aviser, aftenskolevirksomhed, sangkor og kooperativt omkring økonomiske virksomheder som bryggerier, bagerier, indkøbsforeninger mv. - en særlig arbejdersport slår igennem 1910-20.

Organisationssamfundet, fase IV, bl.a. med de landsdækkende masseorganisationer, som vi kendte det fra o. 1910 til 1970 og delvist stadigt har i 'Forenings-Danmark', er endegyldigt slået igennem og professionaliseret; men mindsket ideologisk bevidsthed og stor afstand fra bund til top er ofte et væsentligt problem.

Bevagelse - forening - institution, de fastere foreninger og institutioner vekselvirker indbyrdes og har deres udspring i de løsere og mere holdningsprægede bevægelser; bevægelserne kan flyde videre som løsere kontaktfora og inspirationsstrømme, efter at ikke-tidssvarende foreninger og institutioner er opløst, ligesom ledelseslag fra foreninger og institutioner efter tid, sted og tematik kan være væsentlige inspiratorer og talerør for bevægelsen. Men de fastere foreninger og institutioner er ikke identiske med bevægelsen, de er samfundsforandrende og samfundsbevarende $u d t r y k$ for bevægelsen. 
Bevaegelse, forening, institution

\section{Kristelige, arbejdere, idrætsfolk og nationale i organiseret optræden}

Der er - trods glidende overgange i den sociale praksis - i Danmark en essentiel forskel mellem en folkelig bevægelse og dens organisatoriske og institutionelle manifestationer, som visualiseret i Fig. I.

Gennem mere end halvandet hundrede år har det første folkeligt religiøse røres arvtagere i den grundtvigske bevægelse og i Indre Mission bevidst uden fastere organisation - end ikke et centralt medlemsregister findes eller har nogensinde eksisteret - til at løse praktiske forhold på delområder stiftet og udviklet foreninger og fastere institutioner. Det drejede sig rent praktisk for bevægelserne om at skaffe tag over hovedet til møder, om at tage hånd om og nationalt og kristeligt at påvirke de unge ved at sætte friskoler og højskoler i værk og ideologisk samle bevægelsen ved at udgive blade som Indre Missions Tidende eller Højskolebladet osv. Disse organisationers og institutioners ledere og st $\emptyset$ tter har igen virket tilbage på bevægelsen i en levende vekselvirkning, men de har ikke top-styret bevægelsen - trods en Grundtvigs eller Vilhelm Becks imposante virke og fremtræden. Hvad der ikke længere af under-organisationer eller sær-institutioner var eller er ideologisk og praktisk bæredygtigt på egnen eller landsdækkende har måttet lukke om end ofte under dyb beklagelse. Et eksempel herpå er højskolernes evige eksistenskamp eller de flere hundrede lukkede missionshuse ud over landet, som ikke har resulteret $\mathrm{i}$, at bevægelserne som åndelige strømninger i befolkningen derfor er forsvundet. ${ }^{11}$

Den tidligere så omfattende afholdsbevagelse har oplevet et dramatisk fald fra op mod $10 \%$ af befolkningen engageret ved Første Verdenskrig til i dag blot at være en skygge deraf.

Bevægelser har deres tid - de skyder frem, blomstrer op og visner hen.

Arbejderbevagelsen er blevet dybt berørt af afideologiseringen og organisationseffektivitetens negative sider kendt som 'fagforsteningen' og den store afstand mellem gulv og loft i de faglige organisationer. Dette har næsten kvalt solidariteten og den sociale idé i arbejderbevægelsen meningspåvirkning gennem aviser, fælles politik gennem partiet og fagbevægelsen synligt til stede $\mathrm{i}$ arbejdslivets dagligdag er i dag som oftest 
adskilte størrelser. Socialdemokratiet er i høj grad blevet de nye mellemlags og funktionærgruppers parti, men disse grupper bejler også alle andre på den politiske midte til, og de resterende 'rigtige' arbejdere $\mathrm{i}$ produktionen, de er i høj grad søgt til Dansk Folkeparti.

Kropskulturen i bred forstand med baggrund fra 1860'erne i skyttebevægelsen og tidligt introduceret i højskolerne blev en væsentlig side af det folkelige element og identitetsdannelsen i brede kredse $\mathrm{i}$ befolkningen både på land og i by. Fra 1880'erne kan man tale om en ideologisk kamp ud over landet om tysk-dansk (særligt i byerne) eller den sejrende Lingske gymnastik indtil bruddet 1929 mellem skytterne og gymnasterne. Fra 1890'erne og fremefter blev kropskulturen udvidet med boldspil og alle former for idræt og sport og har siden da været blandt de medlemsmæssigt bredeste af alle folkelige bevægelser. Kropskulturen har fanget alle aldersklasser, men har løbende særligt formået at opfange ungdommen og indgik og indgår i et stadigt vekselspil med andre grene af de folkelige bevægelsers mønster, $\mathrm{fx}$ fra en naturlig plads i højskolen til en særlig arbejderidræt og KFUM og -Ks sports- og idrætsafdelinger. Professionaliseringen af topidrætten og internationaliseringen af konkurrence-elementet fra 1896-olympiaden og fremefter har ikke ændret væsentligt på bredde-idrættens popularitet. Trods massiv offentlig st $\varnothing t t e$, for eksempel til haller og lignende, har frivillighedens princip og de lokale lederes $i k k e$ løn/profitbaserede engagement været og er stadigt et centralt element i kropskulturens form og virke i Danmark. ${ }^{12}$

De faedrelandskarlige, nationale aspekter og det demokratiske element som holdningsbærende foreteelser i dansk samfundsudvikling har begge været aldeles væsentlige $\mathrm{i}$ at engagere brede befolkningsgrupper ideologisk og organisatorisk gennem de sidste små 200 år og som oftest med tiden $i$ et samspil med de ovenanførte bevægelser og deres organisationer og institutioner. Men det er særligt på det helt lokale plan, at meget af disse landsdækkende fænomener er kommet og kommer til det mest konkrete udtryk i den enkeltes bevidsthed, stillingtagen og handlingsmønster omkring vores frikirke, vores missionshus, vores boldklub, vores friskole osv. Danskerne af i dag køber alle ind i butikker som Netto og Bilka, men vi kommer virkeligt op på mærkerne, hvis 'de' vil lukke vores lokale brugs, skønt vi selv økonomisk har kvalt den ved manglende kundetrofasthed.

\section{Samspil mellem lokale forhold og religiøse protester}

Som Gundelach - og den nyere forskning på feltet $\mathrm{i} \emptyset \mathrm{vrigt}-$ mener jeg, at 
væsentlige ændringer i samfundets produktionsliv og -vilkår som landboreformerne 1788-1814 og senere industrialiseringen fra sidst i 1800tallet er afgørende for, at gamle, men fornyede eller helt nye religiøse og livsholdningsmæssige strømninger i befolkningen kan få andet og mere end punktvise og lidet samfundsforandrende nedslag. Men hermed er ikke plæderet for en materialistisk forsimplet reduktionisme fra basis til overbygning, tvært imod. Hvilke fængende personer og hvilken åndelig strømning, der udfylder de nye mulighedsbetingelser eller taber sagen på gulvet, er ikke på forhånd givet, men må i hvert enkelt tilfælde undersøges konkret. Det centrale var og er, at enhver given statsform og $\varnothing$ konomi med tilh $\varnothing$ rende kulturm $\varnothing$ nster, religiøse overbevisninger og fremtrædelsesformer under forandringens vind vil nå situationer, hvor de nedarvede eller strukturerede sociale og kulturelle mønstre for rimelig praktisk og etisk forsvarlig tænkemåde og opførsel ikke længere slår til. Dette medfører hos en del eller mange i samfundet en oplevelse af rodløshed og handlingslammelse - ofte i samtidens kilder beskrevet som en afgrundsdyb følelse af synd og svigten. En sådan sjælelig nedtur gjorde og gør mennesket i situationen åben over for en ny ideologi eller en fornyet religion, som atter vil tillade de involverede mennesker at handle, at leve og tage aktiv stilling til livets og dagligdagens problemer.

Først kan vi i en mental opvågnings- eller vækkelsesfase hos de søgende konstatere en protest mod konkrete forhold på det religiøse eller ideologiske plan ofte med et stærkt drag af fordømmelse af andre. Men afhængig blandt andet af stærke lederskikkelser, karismatiske figurer eller ledelse fra en mindre, toneangivende gruppe, kan vi efterfølgende iagttage mere fremadrettede og socialt konstruktive tiltag - som fx skildret af Hans Kirk i Fiskerne (København, 1928). ${ }^{13}$

Den lokale og mindre omfattende folkelige strømning har altså $\mathrm{i}$ starten ikke nogen fast viden om, hvor den åndeligt eller politiskideologisk set på længere sigt vil hen. Den har ingen faste strukturer, men er mere et netvark af meningsfæller med et løsere mødesystem, som strækker sig over måske mere end et tiår og socialt tiltrækker folk i princippet uden personsanseelse, men i hovedsagen fra middelklassen og de lavere sociallag. ${ }^{14}$ Sjældnere inddrages de socialt set nederste ca. 15 $25 \%$, det egentlige lokale proletariat, ligesom mange fra den lokale elite - måske bortset fra pastoren og skolelæreren - holdt sig tilbage. En fastere organisation og en stærkere kollektiv bevidsthed fremmedes dels af det omgivende samfunds eventuelle modstand (dem-mod-os effekten samt martyriet), fx gennem stivnakkede præster som hos De stærke Jyder eller ved Kertemindevækkelsen, dels derved, at der ud af situationen 
enten indefra fremstod eller udefra tilkom en åndelig og organisatorisk lederskikkelse eller en snæver ledergruppe; en ledelse, der kunne og ville føre de berørte mennesker ud af en ofte truende selvdestruktion eller total indelukkethed i en 'venden-verden-ryggen'.

Mange sådanne løsere samfund synes efter kildematerialet at være gået i sig selv igen for en tid eller permanent. Der kan her peges på, at mange lokale lederskikkelser og præster mærkede og lige så stille føjede sig noget i den retning, som vinden blæste. Hvad skulle menigmand så lokalt med alt det bøvl og den ufred, som man fra andre steder vidste fulgte i kølvandet på en organiseret opposition, ' ja, men når nu både præst og degn og 'de store' havde forbedret sig? Nej tak, ikke hos os, det går jo endda!' - noget i den retning kan vi ind imellem finde i emissærberetningerne fra Christiansfeld og fra de tidlige Indre Missionkolportører. I andre tilfælde fandtes eller fremstod den nødvendige ledelse og struktur til mere varige og betydningsfulde tiltag ikke. Men det, der ikke førte til lokal konflikt eller varige institutioner, vil sjældent afkaste noget givtigt kildemateriale, så vi ved ikke noget om det sporløse og kan ikke vide det. Alt i alt vil vi nok have en tendens til at overvurdere konflikterne og undervurdere de muligvis mange steder, hvor man lokalt hen ad vejen talte sig til rette. Med de f $\varnothing$ rste fors $\varnothing \mathrm{g}$ beredte stilfærdige og beskedne tiltag vejen for den næste generations brede fremvækst af institutionsdannelser fra 1860'erne og frem: med friskoler og højskoler og sparekasser osv. og derfra videre til 1880'ernes organisationssamfund, som vi stadigt lever i eftervirkningerne af efter år 2000.

\section{Stat, markedsøkonomi, modernitet og folkelige bevagelser}

Staten og kommunerne tog sig fra o. 1800 - udover de i Danmark klassiske statsopgaver som skattevæsen, politi og retsvæsen, forsvar, centraladministration, $\varnothing$ konomisk lovgivning, kirken osv. - af en generel modernisering og udvidelse af en række nødvendigt strukturerede forhold i samfundet som brandforsikring, skolevæsen, vejvæsen og transport, socialforsorg, sundhedsvæsen, byggeregulering etc.; dvs. områder af samfundstotaliteten, som det offentlige langt op i 1800-tallet, ja, ind i 1900-tallet i fx England og USA ikke ville - og i Rusland ikke kunne regulere, men overlod til socialt kaos eller private organiserede kræfter at strukturere.

I en trekantrelation mellem den enkelte borger og den offentlige sfære samt den frigjorte økonomis markedsregulering indtrådte de folkelige bevægelser og deres afledte institutioner som et både individuelt 
beskyttende og kollektivt potentielt samfundsforandrende medieringslag. Derfor indeholder de folkelige bevægelser både reaktionære og fremadrettede potentialer i forhold til samfundsudviklingen, ligesom såvel de beskyttende og bevarende træk som de socialt-konstruktivistiske træk løbende kommer til udfoldelse i et stadigt vekselspil med andre samfundsfaktorer og udviklingstendenser. Alt efter øjnene, der ser, og spørgsmålene, der stilles, kan og kunne nutidens forskere og datidens iagttagere derfor finde både positive og negative træk $\mathrm{i}$ de folkelige bevægelsers konkrete fremtrædelsesformer og virke. Men at bevægelserne har været og delvis stadigt er væsentlige for den særlige danske udvikling samt for at forstå denne, benægter ingen seriøse iagttagere.

\section{Bevægelser, frivillighed og samfundsmæssig tvang}

Den stærke statslige modernisering ovenfra og den udefra kommende kapitalistisk organiserede markedsøkonomis gennemslag fra omkring 1840 indeholdt hver for sig og i samspil stærke strukturerende elementer for det enkelte menneske og større grupper af dels direkte tvang (arbejderen ved maskinen, som må følge dens takt), dels indirekte tvang ( $\mathrm{fx}$ bonden over for banken og obligationsejeren). Blandt andet derfor blev og er frivillighedsprincippet i de folkelige bevægelser så væsentligt. Selvom mange med rette oplevede og især i vor tid oplever, $\mathrm{fx}$ arbejdsmarkedets aftalesystemer og organisationer som meget påtvungne, så lå og ligger dette tvangselement mere på det organisatoriske plan end på bevægelses- og ideologiplanet, - men statens magt gennem administration, politi, domstole, love og skattevæsen mv. må ethvert samfundsmedlem erkende - eller betale en høj pris for dumheder i forhold til statsmagten.

Tvangen og aftalesystemet på arbejdsmarkedet var og er udtryk for det asymmetriske magtforhold mellem den enkelte lønmodtager og den organiserede kapital konkret udfoldet $\mathrm{i}$ arbejdsgiverens virke. Om arbejderen ville med i boldklubben, Frem, i arbejdernes begravelseskasse eller holde den socialdemokratiske avis osv. var hans helt frivillige sag at afgøre. Ligeledes var det frivilligt, om gårdmanden ville tilhøre frikirken eller sætte sit barn i friskolen eller ville vælge én sparekasse frem for en anden eller foretrak købmanden frem for brugsen, så længe han betalte enhver sit. Men en politisk frihed til at voelge, et vist mål af social og kulturel frihed og en minimal økonomisk frihed hang og hænger stadigt sammen - det var nemmere for gårdmanden frit at vælge blandt samfundets muligheder end for landarbejderen. Tilsvarende er det i dag nemmere for mellemlags-akademikeren at vælge blandt samfundets 
muligheder end for anden- og tredjegenerationsindvandreren i Århus vest, i Gellerup Parken, selvom de måske begge er arbejdsløse.

Fremdrager vi som eksempel Indre Missions kvinder, der o. 1900 afholdt basar til støtte for missionen i Afrika og til Magdalene hjemmet i København for 'de faldne piger', så var det frivillige engagement noget centralt i et sådant virke, selvom der nok kunne udøves et vist kollektivt socialt tryk på den enkelte for at yde sit til den 'gode sag'. Ser vi i dag efter år 2000 på Indre Missions, KFUM og -Ks og Kirkens Korshærs mange genbrugsbutikker eller på hele det frivillige ledelsesarbejde $\mathrm{i}$ ungdomsorganisationerne samt $\mathrm{i}$ sporten og idrætten og på mange andre samfundsområder lokalt ud over landet, så er frivillighedsprincippet helt grundlæggende. Staten, men især kommunerne, yder ofte deres til de ydre rammer med billig leje eller helt gratis lokaler og haller og anlæg, men livet $\mathrm{i}$ det omfattende foreningsvirke fungerer ikke uden det frivillige ledelses- og hjælpearbejde; sådan blev det udformet for 150 år siden, og sådan fungerer det i bred forstand stadigt i dag ${ }^{15}$ i 'Forenings-Danmark'.

\section{Ånden i bevægelserne og institutionernes strukturelle magt}

Generelt vil jeg mene, at institutionerne og de fastere organisationer til løsning af konkrete lokale og landsdækkende ønsker, forhold og problemer nok var og er i stadig og frugtbar vekselvirkning med bevægelsernes løsere fremtrædelsesform. De fast strukturerede tiltag er ikke kernen i bevægelsernes samfundsmæssige potentiale, de er ikke hovedet, som ser fremad, tænker og føler, men kan snarere lignes med lemmerne, der udfører arbejdet.

Når ånden og en vis fælles ideologi forsvinder ud af bevægelserne, så oph ører efter kortere eller længere tid disses samfundsstrukturerende og samfundsforandrende evne og betydning, ligesom deres afledte institutioner ofte vil fremstå som tomme skaller uden evne til at skabe nyt liv ved indre vækst og ydre knopskydning, som illustreret i Fig. I. Men nogle organisationer vil være blevet så toptunet effektive til at begå sig med held i det moderne samfund, at de efter frigørelse fra det oprindeligt ideologisk engagerende udspring i bevægelserne skaber eller finder sig nye mål og opgaver - organisationens overlevelse og virke er da blevet et formål i sig selv, ligesom ombygning af gamle bygninger, der er blevet taget i brug til helt nye formål. ${ }^{16}$ På Lolland ligger der et tidligere missionshus, som er blevet ombygget til et lokalt svømmebassin; over for hjørnet af Svendsgade og Valdemarsgade i det centrale Ålborg ligger der en tidligere frikirke med tårn og det hele, den huser nu en IT-virksomhed; 
KFUMs gamle højborg i København i Rosenborggade er nu hjemsted for Samfundsfag under universitetet etc. En af de tidligere ledere af den danske fagbevægelse advarede ved sin afgang for ikke så længe siden om en organisationsforstening: vi har sejret, ja, "vi har sejret os ihjel."

Hvis institutionerne med en oprindelig folkelig baggrund stadig har en nødvendig social funktion, men ikke længere ad frivillig og privat vej kan skaffe det nødvendige af penge, medarbejdere og moderne udstyr, så ser vi dem enten lukke eller glide ind under det offentliges vinger og budgetdirigerede logik. De oprindelig medmenneskeligt engagerede medarbejdere med en normalt stor kaldsfølelse bliver desværre efter den offentlige overtagelse ofte langsomt, men sikkert og helt bevidst af fagforening og det offentlige bureaukrati i fællesskab, bibragt en ren lonarbejdermentalitet - gør-dit/gør-dat til fastsat tid og løn, som rationaliseringsprogrammet fastlægger! De tidligere kaldsbevidste bliver frataget eget initiativ og arbejdsengagement med faldende produktivitet og synkende kvalitet og manglende medmenneskelighed i arbejdet til følge. Enhver læser kan i avisen næsten dagligt finde eksempler på en sådan udvikling - det vil sige tilbageskridt - der er til sorg for brugere og medarbejdere og til skade for samfundet som helhed. Omvendt kommer disse negative resultater oftest til lige dele forundring og irritation for det offentlige bureaukrati og de budgetafbalancerende politikere, som til stadighed undrer sig over og ikke kan fatte eller lære, at den menneskelige og sociale virkelighed ikke retter sig efter deres små tal på IT-skærmen.

Når en sådan 'udvikling' er tilendebragt, har den oprindelige og social-konstruktive folkelighed og medmenneskelige ansvarlighed bag institutionen eller initiativet tabt eller udspillet sin rolle. "Lad falde, hvad ikke kan stå", hedder det i en gammel kampsang fra arbejderbevægelsen, og gamle Grundtvig mente jo selv, at "livet er i kamp", hvor der ikke kun er vindere, men også tabere. ${ }^{17}$

\section{Fra klassernes folkelige bevægelser til postmodernitetens: 'hvad så’?}

Efter 1970 er der med transformationen af produktionen fra manuelt til ikke-manuelt arbejde, internationaliseringen og kvindernes verdensrekordhøje indmarch på arbejdsmarkedet tilsyneladende ikke længere behov for og plads til de tidligere klassebaserede partier og organisationer og deres ideologisk-religiøse værdier. Men kravene økonomisk og via militært samarbejde fra den nye verdensorden efter Sovjetstyrets fald samt globaliseringen af hverdagen gennemtvinger en nyorientering. Det 
samme gør truslen fra den ideologisk bevidste konfrontation fra små, men medietiltrækkende muslimske kredse over for næsten oversete, danske demokratiske, sociale og religiøse værdier. Dette har medført en stigende lydhørhed og eftertanke i brede kredse - og en tilsvarende politikeromfavnelse vedrørende, hvad det livsholdningsmæssige og værdibevidste grundlag for den folkelige danskhed egentlig var og er for noget - som fx arbejdernes tidligere paroler: ' $\mathrm{g} \emptyset \mathrm{r}$ din pligt og kræv din ret', eller 'de bredeste skuldre skal bære de tungeste læs' mv. Er denne eftertanke blot en slags tilbageskuende ritualdanse omkring reelt døde værdier under individualitetens og markedskapitalismens uundgåelige fremmarch, eller er der alligevel noget at besinde sig på? ${ }^{18}$

Single case bevægelserne fra 1960'erne og fremad med deres flade struktur og det løse netværk, som kommer og går, vil vi antageligt fortsat se dukke op. Men får de nogen langvarig og dybgående indflydelse på samfundsudviklingen, som de folkelige bevægelser gennem 150 år har haft og delvis stadig har? Kan der findes et fremadrettet og optimistisk, bredt åndeligt og fællesskabsdannende grundlag på resterne af klassesamfundets interesser og bevægelser i mere omfattende befolkningskredse? Hvis $j a$, så ligger hele systemet klar, udviklet gennem 150 år naturligvis ikke kun skabt af de folkelige bevægelser, men i høj grad også af disse i vekselvirkning med andre skabende og bærende kræfter i samfundet ideologisk, kulturelt, politisk og økonomisk.

\section{Forskning $i$ virkningshistorien og $i$ de folkelige bevagelser}

Forskning i de folkelige bevægelser i den her givne kvalitative forstand er central for at udrede og klargøre Grundtvigs virkningshistorie i Danmark og videre ud. For at forstå det sarlige ved den grundtvigske bevægelse på det visionære og religiøse plan samt i dens konkrete samfundsmæssige fremtrædelsesformer og virkemåder må vi også forstå dens modstandere og medspillere $\mathrm{i}$ den etablerede kirke, $\mathrm{i}$ den politiske verden, $\mathrm{i}$ de nationale og de demokratiske dimensioner, i Indre Mission og i husmandsbevægelsen samt ikke mindst i arbejderbevægelsen. I korthed: vi har måske for længe af tilbøjelighed og tidnød set for meget indad i Grundtvig og bevægelsen og for lidt forstået ham og bevægelsen udadtil i det stadige samspil med det omgivende samfund, som han og bevægelsen konstant befandt sig $\mathrm{i}-\mathrm{i}$ en levende vekselvirkning.

Som programerklæring kan jeg måske nok finde en vis anerkendelse for disse synspunkter, og har selv her forsøgt at opstille en nødvendig ramme for forståelse af de folkelige bevægelser. Men samtidig viser 
artiklen og dens første skema hvilken mægtig opgave og hvilket mangeårigt forskningsarbejde, der da ligger foran os.

\section{Fig II - Den komplekse interaktionscirkel}

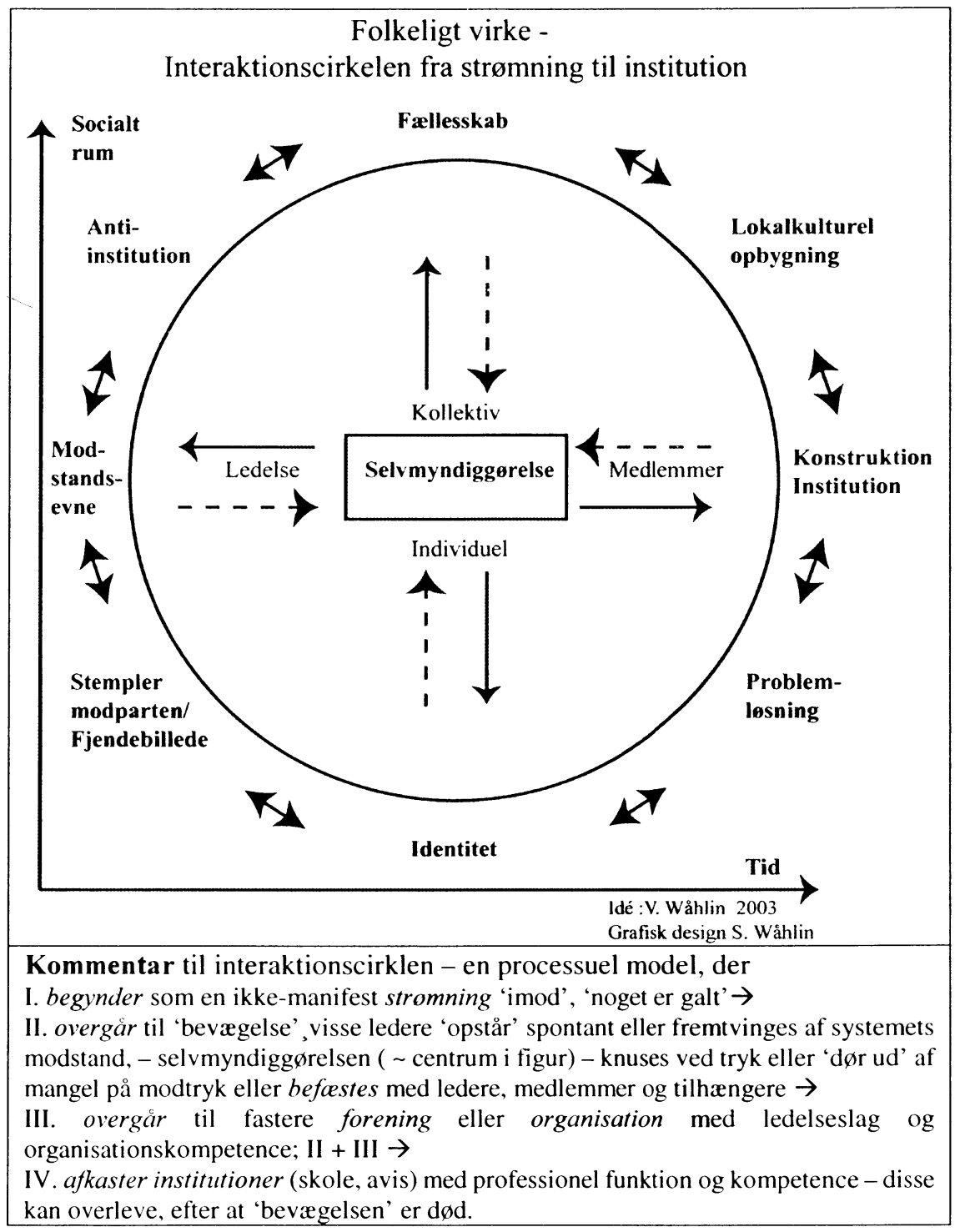


Hidtil har teologer og litteraturforskere præget de videnskabelige studier over en bred front af Grundtvig og hans virkningshistorie, hvilket en gennemgang af forfatterne til Grundtvig-Studiers artikler fra begyndelsen til i dag til fulde demonstrerer. Med den $\emptyset$ gede opmærksomhed på virkningshistorien vil der nødvendigvis fremover komme mere tvarvidenskabelighed ind i denne forskning, hvor antagelig særligt historikere, forskere fra samfundsvidenskaberne og etnologi/antropologi samt uddannelsesforskere har noget af bredere interesse for Grundtvigforståelsen og Grundtvig-receptionen at bidrage med på linie med de senere års glædelige internationalisering af Grundtvig-interessen og Grundtvig-forskningen.

Som et eksempel på konstruktive bidrag fra samfundsvidenskaberne til forståelse af væsentlige sider af de folkelige bevægelser har jeg her bragt Fig. II, den komplekse interaktionscirkel, som en model for, hvorledes en samfundsfaglig strukturtænkning til forståelse af konkrete menneskers tanke- og aktivitetsformer på Nørrebro i København i 1990'erne er udvidet i tid og rum og kompleksitet af mig som historiker omkring det helt centrale tema i de folkelige bevægelser "vi-kan-og-vivil-selv'. Denne proces kaldes af visse filosoffer og samfundsforskere ganske rammende for: selvmyndiggorelse, det vil sige, hvordan fik og får den enkelte og dennes umiddelbart nære kreds $\emptyset$ get indflydelse på egne livsforhold og dermed i en dialektisk proces - som også er en læreproces - indflydelse på samfundets form, virke og fremtid i en løbende og kompleks vekselvirkning - som regel begyndt lokalt, men ofte fortsat nationalt?

Læseren kan selv indsætte forholdene omkring de første religiøse vækkelsesbevægelser, for eksempel Kertemindebevægelsen omkring $1820, \mathrm{og}$ finde, hvorledes modellen indtænkt i et dynamisk forl $\varnothing \mathrm{b}$ faktisk giver mening både vedrørende forholdene omkring 1820 på Fyn og vedrørende de sidste 10-15 år på Nørrebro - eller læseren kan indsætte eksempler fra sin egen livserfaring. ${ }^{19}$

Som blandt andet Kim Arne Pedersens artikel 'Grundtvig på anklagebænken' i dette tidsskrift (2002), $184 \mathrm{ff}$ og mine bidrag her viser, så vil sådanne udvidelser af perspektivet $\mathrm{i}$ Grundtvig-forskningen hos forfatterne og i temavalget medføre en øget opmærksomhed på dagsaktuelle og globale problemstillinger. Bidragene vil ofte vise et mere synliggjort, personligt engagement i fremlæggelserne, jf. også temaerne for Vartovs og Center for Grundtvigstudiers mange foredragsdage og seminarer. Alt efter temperament, livssyn og forskningsforståelse kan man beklage eller prise en sådan drejning i Grundtvig-Studier bort fra en 
forhen ofte lidt støvet og fin, humanistisk årbog og over mod mere nutidsengagerende fremlæggelser, men stadig af høj videnskabelig værdi; undgås kan omlægningen dog ikke, for ellers går de yngre - som alt for snart er midaldrende - forskere andetsteds hen med resultaterne af deres studier.

\section{Noter}

H. Sanders og O. Vind (red.), Grundtvig - nycklen till det danska? Centrum f. Danmarksstudier, I (Lund, 2003). Tak til Sidsel Wåhlin for hjælp med udformning og datalogisk behandling af Skema og Fig. I og II.

V. Wåhlin, 'Opposition og statsmagt' i Fl. Mikkelsen (red.), Protest og oprør (1986), 105-130 og det udførlige noteapparat der.

Jf. L. Holbergs mange satirer i komedierne fra $\varnothing \varnothing r$ midten af 1700 -tallet om dansk snusfornuft over for akademisk latinsk hovmod eller forgabelse i det franske eller det ubehagelige i militærtjenesten fremhævet ved officerernes tyske sprog etc. - det centrale er, at hvis den norsk-fødte Holberg ikke havde talt til en klar bevidsthed hos sit københavnske publikum om dansk som det givne og positive, så havde hans komik og satire omkring fremmedsprogssnobberiet slet ikke virket. Humoren kræver fælles værdiopfattelse for at virke ved sine barokke brud på det forventelige og fælles. Efter 12 års bolig i Brabrand og i Gellerup Parkens miljø vil jeg på det bestemteste advare selv min værste fjende mod på holbergsk vis derude i 2003 at ironisere over de lokale imamers arabiske sprogfejl eller fortolkningslogiske fejlskud - med mindre da sådanne vittige hoveder i bogstaveligste forstand vil vove et øje eller mere. Min pointe er, at menigmand i København o. 1730 udmærket vidste, hvad dansk var for noget, især når det blev klargjort $\mathrm{i}$ et modsætningsforhold til fx tysk eller fransk; der er altså ikke tale om en 'opfindelse' af det danske som noget særligt en generation senere sidst i 1700-tallet. Det er forståelsen af, hvem der er 'folket', som ændres ved i en lang proces at udbredes til stadigt flere samfundslag: borgere, bønder, husmænd, arbejdere osv. og modsvarende bliver godtaget af disse som opgående i et forpligtende, folkeligt fællesskab.

4 Generelt er oversigtsværket Ole Feldbæk (red.), Dansk identitetshistorie, 14 (1991 f.), men her henvises særligt til V. Wåhlin, 'Denmark, SchleswigHolstein and Grundtvig in the 19th Century' i A. M. Allchin et al.(eds.) Heritage and Prophecy (Århus, 1993), 243-70 og V. Wåhlin (udg. af) Nic. Fr. Severin Grundtvig, 'Politiske Betragtninger med Blik paa Danmark og Holsteen', 16-58 samt sammesteds V. Wåhlin, 'Grundtvig i politik', Grundtvig-Studier (1994), 59-91 samt samme 'Local History as a Popular Movement' (manus i trykken., 2003). 
Af nyere forskning med disse opfattelser kan anføres Peter Gundelach, Sociale bevagelser og samfundsandringer. Nye sociale grupperinger og deres organisationsformer ved overgangen til andrede samfundstyper (1988). Gundelach ser en brudflade efter midten af 1800-tallet i samfundsudviklingen ved overgangen til det moderne industrisamfund som væsentlig i fremvæksten af de ældre, sociale bevægelser af religiøs, afholdsmæssig og demokratisk-politisk art fulgt af tidlig kvindebevægelse og arbejderbevægelse. Han fortsætter denne indkredsning med artiklen, 'Sammenhold i værdibaserede organisationer - mellem stat og marked' i Søren Christensen (red.), I den gode sags tjeneste - frivillige organisationeri Danmark (1995). Drude Dahlerup, Rødstrømperne, I-II (1998) behandler historisk og med bred teoretisk baggrund den nye kvindebevægelse fra 1960'erne til 1980'erne også ud fra et internationalt perspektiv om en protestbevægelse, mens Søren Hein Rasmussen i Sare Alliancer (1999) mere end protesten fokuserer på, hvorledes i forvejen organisationsvante ret små grupper griber dette protestpotentiale og giver det målsætning og mæle og en vis indflydelse en tid omkring enkeltsager som Vietnam krigen, Verdensbanken etc. uden i det ydre at bryde med den flade og stormødedemokratiske struktur.

Ingen andre lande har et blot tilnærmelsesvis modstykke til Højskolesangbogen i indhold og udbredelse, varighed og slidstyrke om værdierne for hele samfundet ved det kristelige, ved det demokratiske, ved landet geografisk, landskabeligt og lokalt, ved det historiske, ved det sproglige og ved den danske kultur - i en sum: det uden ironi prisværdige som ofte uden forbehold bevares og forsvares som det ægte folkeligt danske - også, når dette egentlig er udgået fra eller er elitært som Dannebrog, kongehuset, H. C. Andersen, Skagensmalerne, Carlsberg øl, Olsenbanden og håndboldpigerne. Den østrigsk-australske forsker Hans Kuhn blev ved mødet dermed så forundret og betaget af dette kollektive og folkelige fænomen, at han efter mange års studier udgav på engelsk en af de mest indforståede bøger herom, Defining a Nation in Song (1998).

I en del år efter Anden Verdenskrig fremhævede en række forskere og offentlige debattører den kvalitative folkelighedsforståelse, antagelig med baggrund i den nødvendige nationale forsoning efter Verdenskrigens skarpe indre modsætninger. Som et indflydelsesrigt arbejde kan fremhæves Roar Skovmand, De folkelige Bevagelser i Danmark (1951), der op til o. 1980 trods sit oversigtspræg var standardværket om emnet. Da venstrefløjens kritik af den vitterligt udjævnende tendens vedrørende sociale konflikter og borgerliggørelsen i Skovmands folkelighedsbegreb faldt sammen med dels den nye anti-nationale og pro-europæiske internationaliseringsbølge, dels de nye teoretiske strømninger fra især USA inden for samfundsvidenskaberne, 
så kom folkelighedsforståelsen sammen med Højskolesangbogen, den grundtvigske skoleverden, den nationale selvforståelses selvtilstrækkelighed og lukkethed, den evige lokalpatriotisme og Grundtvig selv ud i stærkt stormvejr, jf. Kim Arne Pedersens artikel 'Grundtvig på anklagebænken' i Grundtvig-Studier (2002), 184-251. I Ole Feldbæk (red.), Dansk identitetshistorie, 1-4 (1991-92) bliver danskhed og folkelighed som forventeligt grundigt og sagligt behandlet fra mange vinkler, som ét blandt flere samfundsmæssigt sammenkittende elementer fra 1840-1970 - men dog med en kritisk distance, der måske ikke helt lader de også positive sider ved folkeligheden komme til udtryk.

Jf. blandt andet flere artikler af V. Wåhlin, dels i fx Grundtvig-Studier (1989-90), 246-303, dels i Scandinavian Journal of History, V (1980) og XI (1986) samt i den store artikel 'Ikke stykkevist og delt' i T. Bekker-Nielsen (red), Stykkevis og delt. Fem essays om Grundtvig og grundtvigianisme (1986), 9-52.

Med baggrund i den internationale komparative forskning omkring konfliktog protest-aspekternes samfundsforandrende potentiale og virkning i fremvæksten af de moderne vestlige samfund udgav Flemming Mikkelsen i 1986 bogen Protest og oprør, med bidrag fra bl.a. Vagn Wåhlin om 'Opposition og statsmagt' (om de legale rammer for organiseret optræden under enevælden og herunder for kollektiv protest). Skønt ingen vel, og heller ikke jeg, underkender den socialt konstruktive betydning i særlige situationer af kollektive konflikttrusler og konkrete, organiserede konflikter som fx borgerskabets march til kong Frederik VII i marts 1848 om en ny regering og en demokratisk forfatning, eller den store arbejdsmarkedskonflikt 1899, så forekommer netop set i et 200-årigt perspektiv den danske samfundsudviklingsmodel med hverandre gensidigt afbalancerende og organiserede økonomiske, sociale, kulturelle, religiøse og politiskideologiske interesser at være et frugtbart alternativ til revolutioner og den politiske 'winner-takes-all' praksis fra USA og England. Men den danske konsensusmodel forudsætter en i alle betydningsfulde samfundslag bredt accepteret social, ideologisk og politisk kultur og praksis. Netop her blev og bliver kombinationen af formelt demokrati og folkeligt engagement og medborgerlig fælles ansvarsfølelse helt central - og noget i den retning af samfundsmæssig ansvarlighed ikke blot oppefra, men især nedefra udvikledes og videreførtes i de folkelige bevægelser. I den forstand er 'folkelig' et plus-ord trods de tendenser til national og kulturel selvgodhed og den næsten reaktionære fastholden ved nogle antageligt forældede værdisæt fra 1800-tallet og tiden før Anden Verdenskrig, som må erkendes.

Siden sidst i 1980'erne, men også tidligere, har denne interesse for de mentale og bløde kulturelle sider af de folkelige bevægelser - og især de 
religiøse aspekter - været et vigtigt tema i mere end 50 bachelorprojektopgaver eksamineret hos mig på Historisk Institut, Aarhus Universitet, og har ligeledes været et centralt tema i mindst 20 hovedfagsspecialer $\mathrm{i}$ historie. Geografisk har der i disse universitetsarbejder mest været tale om lokale eller egnsmæssige studier, hvor de mere end 800 lokalarkiver, vi nu har i landet, har været et næsten uudtømmeligt reservoir af kildemateriale. Specialerne kan nu findes elektronisk via Historisk Instituts bibliotek, mens bachelorprojektopgaverne kun befinder sig i kopi på mit kontor på Historie under Institut for Historie og Områdestudier, Aarhus Universitet.

V. Wåhlin (red.), Skolevirke og trosliv (om Indre Missions høj- og efterskoler) (1991) - heraf fremgår det klart, at især ungdomsskolerne i den sidste menneskealder har haft en forrygende fremgang, mens den tidligere blomstrende kreds af Indre Missions-højskoler siden 1970 ikke har kunnet holde fanen højt og overleve.

Niels Kayser Nielsen, Aarhus Universitet og Ove Korsgaard, Danmarks Pædagogiske Universitet, har i de senere år været foregangsmænd for at få indsat gymnastikken og breddeidrætten $\mathrm{i}$ et videnskabeligt forskningsperspektiv, kulturelt-ideologisk og historisk, og har fået fremdraget linierne tilbage både til Grundtvig og til de folkelige bevægelser, jf. blandt andre $\mathrm{O}$. Korsgaard, Kampen om kroppen (1982) og samme, 'Delingsføreruddannelse og demokratiuddannelse' i Vartovbogen (1997), 58-68 samt N. Kayser Nielsen, Krop og oplysning. Om kropskultur i Danmark 1780-1900 (1993) og 'Pengene eller livet - om offentlig støtte til skyttebevægelsen i 1800tallet' i Idratshistorisk Årbog (1989), 4-35 samt N. K. Nielsen og V. Wåhlins anførte diskussion af S. Ehlers disputats (se note 15).

I den af pastor Emil Steenwinckel for Indre Mission i årene 1932-56 udgivne serie, Hjemliv og Trosliv, I-XX, med erindringer og beskrivelser af dels lokale missionssamfund, dels karismatiske lederfigurer blandt især missionske præster og skolelærere samt en del lægfolk, er der mange eksempler på sådanne synds- og forladthedsoplevelser samt, om end neddæmpet, af dømmesygen over for andre. Omvendt er også de frigørende sociale kræfter gennem sammenholdet i de på toppen over 1200 lokale Indre Missions samfund omfattende beskrevet deri. Med en inspiration tilbage til Max Webers Makt og byrokrati, (no. udvalg, Oslo, 1976) generelle fremhævelse af karismatiske lederskikkelsers betydning også i religiøse sammenhænge, er ledelsens art og fremtrædelsesform i især folkeligt religiøse bevægelser unders $\emptyset \mathrm{gt} i$ en række af de omtalte universitetsopgaver (note 10). Det ses blandt andet, at åndeligt og organisatorisk lederskab i praksis ofte ikke var og er koncentreret i én person, men kunne ligge hos to eller flere, der samlet besad og gav plads for hinanden vedr. det nødvendige af social energi, religiøse talegaver, organisationstalent, økonomisk indsigt, 
fastholdenhed og evne til at modstå langvarigt socialt og mentalt pres, selvom én enkelt udadtil fremtrådte som lederen. De religiøst vaktes tendens til at søge sig et overkommeligt forbillede efter Luthers anvisning og en lignende tendens hos modstanderne i det omgivende samfund, der helst ville have en leder at bekæmpe, førte ofte samlet til, at en bestemt person blev presset ind i en oprindelig ikke ønsket rolle som leder. Men ved at personen tog ansvaret og byrden på sig, voksede han ofte med opgaven, så han med tiden blev det, han oprindeligt ikke var, en karismatisk leder.

Af de mange beretninger fra Indre Missions kredse i Hjemliv og Trosliv (note 13) får læseren et indtryk af en socialfordeling hos de vakte før 184050 noget over middel i det agrare Danmark, fordi bl.a. præsterne fylder så meget. Specialer, jeg har vejledt og bedømt om socialfordelingen 1820-40 blandt de vakte, viser nok nogen overvægt til de yngre og endnu ikke veletablerede i agrarsamfundet blandt de vakte, men da vi når op omkring midten af 1800-tallet, så modsvarer mine og $\mathrm{A}$. Pontoppidan-Thyssens iagttagelser hinanden: deltagerne i vækkelserne udgjorde socialt set et rimeligt gennemsnit af egnens beboere. P. G. Lindhardts forkætrede tese om Indre Mission som de fattiges religion passer ganske enkelt ikke, heller ikke for den tidligere fase. Fra omkring $1880 \mathrm{kan}$ vi via bestyrelsesposter i Indre Missions institutioner, lister over pengegaver mv. se, at det på landet da var de solide gårdmænd, som dominerede i Missionen, og denne lignede både i sociale handlingsmønstre og i social sammensætning i høj grad den grundtvigske bevægelse. Præster, højskolelærere og lærere sammen med mejerister fra de søndagshvilende mejerier og Indre Missions folk i menighedsråd og kommunalbestyrelser etc. udgjorde fra 1880 'erne en faktisk elite i Indre Mission, selvom bevægelsen gjorde meget ud af at fremhæve betydningen af ledende lægprædikanter og kolportører. Indre Missions selvsupplerende hovedbestyrelse og mange aktiviteter, nu fra Indre Missions Hus i Fredericia, har sammen med Indre Missions Tidende gennem tiden skabt et fastere fælles ståsted for Indre Mission end de grundtvigskes næsten ikke-eksisterende fælles holdninger og strukturelle fællesskab trods institutioner som Vartov og højskolernes flagskib, Askov, samt Højskolebladet $\mathrm{mv}$.; jeg har her lagt mere vægt på fællestrækkene end på forskellene i de to bevægelser.

15 Søren Ehlers, Ungdomsliv. Studier i den folkeoplysende virksomhed for unge i Danmark 1900 -1925 (2000), (kritisk diskuteret andetsteds i Grundtvig-Studier, 2003) har taget et tiltrængt opgør med især den grundtvigiansk inspirerede opfattelse af, at ideologi og socialt engagement var det væsentlige $\mathrm{i}$ ungdomsarbejdet, og især at dette foregik uden offentlig indblanding eller afhængighed deraf. Men uden penge går den ikke, og også gårdmændene og de grundtvigske og venstrefolk søgte flittigt økonomisk 
støtte hos stat og kommuner og søgte via statsmagtens lovgivning indflydelse på rammerne for ungdomsarbejdet. Så i realiteten var der et tæt samvirke mellem det offentlige og de frivillige bevægelsers praktiske organisationer og institutioner $\mathrm{i}$ hvert fald på det centrale område for ungdomsarbejdet. Andre aspekter af afhandlingen er blevet mere kritisk vurderet, jf. N. Kayser Nielsen og V. Wåhlin, 'Folkeoplysning og ungdomsliv i Danmark 1920-25' i Historie, 1 (2001), 77-112. Om frivillighedsprincippet i de folkelige bevægelser modsat kirkens, militærets, skolens osv. offentlige organisationsformer, jf. litt. i note 2 og 5 .

Under inspiration fra især amerikansk organisationssociologi havde man allerede under det store svenske Folkrörelsesprojekt under ledelse af blandt andre S. Lundkvist iagttaget (S. Lundkvist, Folkrörelserna i det svenska samhället 1850-1920(1977) og min diskussion derom, 'Omkring studiet af de folkelige bevægelser', i (svensk) Historisk Tidskrift (1979), 113-151), at oprindeligt af bevægelserne skabte organisationer med et vist ideologisk grundlag kunne blive så næsten materielt faste i struktur og social eksistens, at de efterhånden, som samfundet ændredes, i vekslende rækkefølge først skiftede praksis, siden skiftede målsætning og til slut skiftede navn - eller også blev nedlagt som ikke funktionelle. Jf. tilsvarende forhold vedrørende flere af den danske arbejderbevægelses organisationer og institutionelle flagskibe som avisen Socialdemokraten-Aktuelt, radiokæden Arako, bryggeriet Stjernen, Arbejdernes Ligkistemagasin, mf1., hvor Arbejdernes Landsbank snart er ene om at klare sig. Eller tænk på tilsvarende forhold vedrørende mange af gård- og husmændenes lokalaviser, andelsmejerier, brugser, sparekasser, kreditforeninger - og betænk, hvor mange forsamlingshuse der er gået til, og hvordan resten kun overlever, fordi en ny bølge af lokalpatriotisme siden 1970'erne i sidste øjeblik har reddet dem.

På både mit forrige universitetshold om 'Folkelige bevægelser' og mit i sommeren 2003 afsluttede hold derom havde mere end en tredjedel af studenterne været eller var stadig aktivt engageret som ledere i FDF og KFUM og -K, trænere i idræt, ambulancekørere for Røde Kors, i politiske ungdomsorganisationer, i universitetsorganer osv., ligesom ca. $20 \%$ af den voksne befolkning er aktivt engageret som ledere mv. i det frivillige foreningsarbejde (jf. Weekendavisen, II, s. 2, 17.10.2003) - så den lidt misantropiske tone i hovedteksten vedrørende det samfundsmæssige engagement holder nok ikke generelt eller over for den elite af ungdommen, vi møder på universitetet. Men mine 12 år i Brabrand ved Gellerup Parken og diverse bestyrelsesposter derude giver mig god grund til mistrøstighed vedrørende en positiv samfundskonstituerende vekselvirkning mellem det folkelige Danmark og det nye slum-proletariats unge, vi selv har stuvet sammen dér. 
Dansk Folkepartis årsmøde i weekenden 12.-13. oktober 2002 i Vejle blev i et to timer langt TV-indslag omkring midnat 15.-16. oktober, kl. 0.30-02.30 bragt på DK4. Indledningens faneindmarch med flere snese dannebrogsfaner frembåret af almindelige kvinder og ikke af veltrimmede og ensartet, smukt påklædte gymnaster, den fælles afsyngelse af nationale sange med lederfiguren Kristian Thulesen Dahl ved flyglet og panoreringerne ud over deltagerne viste helt umisforståeligt, at her samledes i egen selvforståelse det folkelige Danmark og ikke elitens Danmark. Deltagerne var trygge ved og stolte af, hvem de var, og hvad de havde opnået på kort tid, og der var ingen spindoktor til at dirigere klapsalverne efter ledernes taler mod en baggrund af de rød-hvide faner, bifaldet kom ægte og med stående ovation.

Det kristelige og nationale i korsfanen, det folkelige i fællessangene og det sociale engagement over for ældre og svage i programtalerne og den klare afstandtagen fra mere union i Europa og dermed for mere dansk selvstændighed gik rent ind med partiprogrammets fremhævelse af samme; navnet Dansk Folkeparti blev bekræftet.

I sin sidste bog Danskerne først (2002), har Informations chefredakt $\varnothing \mathrm{r}$ David Trads taget sig grundigt og særdeles kritisk af Dansk Folkeparti; men han overdriver kritikken ved stædigt at pådutte partiet mærkesager fra Glistrups Fremskridtsparti, skønt Dansk Folkeparti klart og tydeligt i sit program og sin politiske praksis siden 2001 har taget afstand herfra. Jf. også Weekendavisen (18.10.2002), 2, hvor Arne Hardis bemærker slægtskabet i partiets nye sangbog med højskolesangbogens kernesange samt, at der kun er medtaget én arbejdersang.

Efter at have set klip fra LOs kongres, fra Socialdemokraternes og fra blandt andet Det Radikale Venstres kongres, må man trods disses mere professionelle arrangører og mere scenevante talere alligevel tænke over, om det kun har været frustration over indvandrerproblemerne og angsten for globaliseringens kræfter, der med 22 mandater bragte Dansk Folkeparti ind i Folketinget som et rent protestparti, - eller om partiet har fat i noget, som de andre har ganske glemt eller har mistet forståelsen for eller helst, men forgæves, vil mane i jorden - fx det kvalitative og nære i folkeligheden over for det elitære og fjerne i europæiseringen og globaliseringen.

Modellen blev af $\mathrm{V}$. Wåhlin demonstreret på Grundtvig-Selskabets årsmøde (8.1.2003). Den har sin baggrund i 'Interaktionscirklen' fra Bolette M. Christensen, 'Selvorganisering og demokratisk netværkskultur' i Fl. Mikkelsen (red.), Bevagelser i demokrati. Foreninger og kollektive aktioner i Danmark (Aarhus, 2002), 130-46. Når en model, som en slags redskab for tanken, kan udstrækkes i tid over 200 år og udvides i geografisk rum fra Fyn til Nørrebro og udstrækkes i social relevans fra religiøst vakte almuefolk af småbønder til den moderne storbys splittede og kulturelt sammentvungne 
beboere, så ændrer modellen status og nærmer sig til en egentlig teori om mentale og sociale forholds samspil i en selvmyndiggørelsesproces. Kommende anvendelse af modellen med konstruktive resultater i empirien $i$ en række konkrete delstudier vil vise, om der her er fremlagt en genuin teori, eller blot en mere begrænset model. 